Article

\title{
Study on Fast Cold Start-Up Method of Proton Exchange Membrane Fuel Cell Based on Electric Heating Technology
}

\author{
Wei Jiang ${ }^{1}$, Ke Song ${ }^{2, *}$, Bailin Zheng ${ }^{1, *}$, Yongchuan $\mathrm{Xu}{ }^{1}$ and Ruoshi Fang ${ }^{1}$ \\ 1 School of Aerospace Engineering and Applied Mechanics, Tongji University, Shanghai 200092, China; \\ 1910094@tongji.edu.cn (W.J.); 1610515@tongji.edu.cn (Y.X.); 1810874@tongji.edu.cn (R.F.) \\ 2 School of Automotive Studies, Tongji University, Shanghai 200092, China \\ * Correspondence: ke_song@tongji.edu.cn (K.S.); blzheng@tongji.edu.cn (B.Z.)
}

Received: 7 July 2020; Accepted: 19 August 2020; Published: 28 August 2020

\begin{abstract}
In order to realize the low temperature and rapid cold start-up of a proton exchange membrane fuel cell stack, a dynamic model containing 40 single proton exchange membrane fuel cells is established to estimate the melting time of the proton exchange membrane fuel cell stack as well as to analyze the melting process of the ice by using the obtained liquid-solid boundary. The methods of proton exchange membrane electric heating and electrothermal film heating are utilized to achieve cold start-up of the proton exchange membrane fuel cell (PEMFC). The fluid simulation software fluent is used to simulate and analyze the process of melting ice. The solidification and melting model and multi-phase flow model are introduced. The pressure-implicit with splitting of operators algorithm is also adopted. The results show that both the proton exchange membrane electric heating technology and the electrothermal film heating method can achieve rapid cold start-up. The interior ice of the proton exchange membrane fuel cell stack melts first, while the first and 40th pieces melt afterwards. The ice melting time of the proton exchange membrane fuel cell stack is $32.5 \mathrm{~s}$ and $36.5 \mathrm{~s}$ with the two methods, respectively. In the end, the effect of different electrothermal film structures on cold start-up performance is studied, and three types of pore diameter electrothermal films are established. It is found that the electrothermal film with small holes melts completely first, and the electrothermal film with large holes melts completely last.
\end{abstract}

Keywords: proton exchange membrane fuel cell; cold start-up; proton exchange membrane; multi-phase flow; electrothermal film

\section{Introduction}

Proton exchange membrane fuel cells (PEMFCs) are a novel power generation technology which has a broad application prospect. Since its power generation reaction is not restricted by the Carnot Cycle, so the theoretical power generation efficiency of the fuel cell could reach $80 \%$. Considering the internal resistance and fuel utilization (currently 80-85\%) and other factors, the final direct power generation efficiency can reach $45-60 \%$. PEMFCs also have the advantages of low operating temperature, fast start-up, simple structure, convenient operation and zero emissions, etc. Nowadays, PEMFC is mainly used in large power generation equipment, household power stations, standby electric supply, transportation and aerospace fields. At the same time, PEMFCs do not have technological shortcomings such as a long charging time and the short range of lithium-ion battery electric vehicles [1]. Thus, it has gradually attracted more attention in the field of new energy vehicles and is considered as an important direction for the sustainable development of the future automobile industry. PEMFC, as vehicle power, could work efficiently in the complex environments such as start-stop, cold start-up (or sub-zero 
start-up), high potential, voltage cycling, high current, air impurities and so on. As it is often inevitable that a vehicle will drive below $0{ }^{\circ} \mathrm{C}$, cold start-up conditions pose the biggest challenge to fuel cell vehicles in the winter which is the serious bottleneck restricting the commercial use of fuel cells [2]. Therefore, the successful commercialization of PEMFCs in automotive applications must achieve the goal of rapid start-up at low temperatures, that is, "cold start-up" of a PEMFC. The reason for the start-up failure below zero is generally considered to be that the water of the reaction freezes inside the catalyst layer which results in a decrease in the catalytic activity of the catalyst layer and impeded oxygen transfer. The chemical reaction would stop because the reaction site is blocked. Moreover, icing may lead to serious damage of the structure of the membrane electrode assembly (MEA) [3-5]. Therefore, the realization of the technology for cold start-up is an important factor for the application of PEMFC in automobiles.

In 2010, the US Department of Energy proposed specific technical indicators for the fuel cells' cold start-up process. At $-20^{\circ} \mathrm{C}$, the fuel cells reached $90 \%$ of their rated power within $30 \mathrm{~s}$ after start-up [6]. The US Energy Agency plans to realize the self-starting of the power system of PEMFCs at $-30{ }^{\circ} \mathrm{C}$ in 2020 and reach $50 \%$ output power within 30 s. According to the "Thirteenth Five-Year Plan", China plans to break through $-30^{\circ} \mathrm{C}$ fuel cell storage and start-up technologies in 2020 . On the other hand, fuel cell vehicles from Toyota Motor Corporation and Honda Motor Corporation have achieved cold start-up of $-37^{\circ} \mathrm{C}$ and $-30{ }^{\circ} \mathrm{C}$, respectively [7]. United Technologies Corporation (UTC) achieved 34\% of its power within $30 \mathrm{~s}$ at $-30^{\circ} \mathrm{C}$ [6]. The "Sequel" fuel cell vehicle launched by General Motors also achieved a successful start-up at $-20^{\circ} \mathrm{C}$, which can provide power after $30 \mathrm{~s}$ of start-up. In China, the fuel cell units have only initially realized the fuel cell system storage and start-up at $-10^{\circ} \mathrm{C}$ [8].

In recent decades, a large number of numerical and experimental studies have been performed on the cold start-up characteristics of PEMFC. At present, the main methods to solve the low temperature cold start of the fuel cell vehicles are to adjust the intake parameters, DC resistance heating, coolant heating, hot air purging hydrogen/oxygen catalytic reaction in the PEMFC, etc.

Du et al. [9] proposed the maximum power cold start-up method for accomplishing PEMFC cold start-up. The results show that the maximum power cold start-up mode has a stronger starting ability compared with the constant voltage and current modes when the maximum power cold start method is utilized. Kim et al. [10] adopted the hydrogen-purge PEMFC method at cathode side during cold start-up process. Their study results show that the hydrogen-purge method can effectively remove the cathode water and enhance the cold start-up performance of a PEMFC. Hou et al. [5] investigated the process of PEMFC freeze degradation utilizing 20 freeze/thaw cycles of two fuel cells; gas purging was adopted immediately, which indicated that the risk of freezing/thawing cycle can be reduced by reducing the water content of the catalyst. Moreover, to assist PEMFC start-up from $-20{ }^{\circ} \mathrm{C}$, Guo et al. [11] adopted an anodic hydrogen-oxygen catalytic reaction, which was studied by establishing a 3D heterogeneous cold start-up method of hydrogen-oxygen catalytic reaction. The results show that the heating position of the electrode has no significant effect on the catalytic reaction, and the starting current density is moderate. At the same time, the humidification of the anode also reduces the ohmic potential of the film, which improves the cold start-up behavior. By considering the influence of the different preheating methods and control strategies for PEMFC stack cold start-up [12], Zhan et al. proposed a phase-in preheating method. It is found that the corresponding optimal preheating method is to preheat the stack by air and end plates simultaneously.

Although these methods have achieved the cold start-up to some extent, the cold start-up time is still too long, and there is still a lot of room for improvement.

Nanoscale carbon materials containing carbon nanotubes (CNTs) [13-19] and graphene [20-28] have been widely used recently based on their outstanding electrical conductivity, relative structural stability and high heating efficiency, which make it possible to realize cold start to PEMFC.

Li et al. [29] prepared graphene nanosheets and found that the steady-state temperature of the films increases from 32 to $139{ }^{\circ} \mathrm{C}$ while the applied voltage rises from 5 to $30 \mathrm{~V}$. Luo et al. [30] prepared electrothermal films, which present sensitive electrothermal behavior, and a steady-state 
temperature of $140{ }^{\circ} \mathrm{C}$ at $10 \mathrm{~V}$. Su et al. [31] prepared multiwalled carbon nanotubes (MWCNT) film with electro-thermal effects, which exhibited excellent electrothermal effect and a high conductivity. The temperature of film is up to $60^{\circ} \mathrm{C}$ within $60 \mathrm{~s}$ under an applied voltage of $30 \mathrm{~V}$ to promote the fast speed melting of ice within $34 \mathrm{~s}$. Sun et al. [32] adopted a novel method to produce high performance graphene films for heating applications. The films show excellent heating and defogging performances, and reach a steady-state temperature of $127.5^{\circ} \mathrm{C}$ when $40 \mathrm{~V}$ is exerted for $60 \mathrm{~s}$.

So far, the studies on cold start-up of fuel cells only mainly focus on the single fuel cell, and there are very few studies regarding the melting process of the internal ice of the PEMFC stack and the method of electric heating to achieve cold start-up. In this paper, we introduce the constant power density as the input condition and utilize two heating methods to achieve cold start-up: one is to heat by the proton exchange membrane (PEM), and another is by the electrothermal membrane (ETF) inserted between the gas diffusion layer and the flow channel. Numerical calculations are carried out as follows: a two-phase non-steady-state model for cold start of a 40-layer two-dimensional PEMFC stack is established to track the solid/liquid interface and analyze the melting process in a PEMFC stack. Based on this model, the PEMFC stack heating and melting process is analyzed under the condition of residual water in the reactor before the start-up and the melting time of the PEMFC stack is predicted. Furthermore, a three-dimensional model of an actual single fuel cell is established and the ETF is placed on the flow channel. At last, the effect of different ETF hole sizes is studied for the cold start-up.

\section{Model}

\subsection{Model Equation}

(1) The energy conservation equation in the solid region (such as end plates and gas flow channel) within the PEMFC stack is expressed by

$$
\frac{\partial}{\partial t}\left(\rho_{\mathrm{s}} h_{\mathrm{s}}\right)=\nabla \cdot\left(k_{\mathrm{s}} \nabla T_{\mathrm{s}}\right)
$$

where $\rho_{\mathrm{s}}, h_{\mathrm{s}}, k_{\mathrm{s}}, T_{\mathrm{s}}$ are the density, enthalpy, thermal conductivity, and temperature of the solid region material, respectively.

(2) The two liquid/solid phases in the fluid may coexist. Therefore, the volume of fluid (VOF) model as well as the solidification and melting model are used to observe the water/ice boundary and control the melting process.

The volume fraction of each kind of the fluids can be tracked by utilizing the VOF model. A continuity equation for the volume fraction of one (or more) of the phases is adopted to monitor the interface(s) between the phases. For the $q^{\text {th }}$ phase, this equation is given by

$$
\frac{1}{\rho_{q}}\left[\frac{\partial}{\partial t}\left(\alpha_{q} \rho_{q}\right)+\nabla \cdot\left(\alpha_{q} \rho_{q} \overrightarrow{v_{q}}\right)=S_{a_{q}}+\sum_{p=1}^{n}\left(\dot{m}_{p q}-\dot{m}_{q p}\right)\right]
$$

where $\dot{m}_{p q}$ is the mass transfer from phase $q$ to phase $p, \dot{m}_{p q}$ is the mass transfer from phase $p$ to phase $q$, and $S_{a_{q}}$ is the source term. The volume fraction equation will not be used to solve for the primary phase due to the reason that the volume fraction of the primary-phase will be calculated according to the following constraints

$$
\sum_{q=1}^{n} a_{q}=1
$$

The problem of solidification and melting fluid flow within a certain temperature or temperature range can be solved by the solidification and melting model. Instead of tracking the liquid-solid boundary, the liquid-solid mushy zone is considered porous and its porosity is equal to the liquid fraction. 
The energy equation in the liquid region is shown as

$$
\begin{gathered}
\frac{\partial}{\partial t}\left(\rho_{\mathrm{q}} E_{\mathrm{q}}\right)=\nabla \cdot\left(k_{\mathrm{q}} \nabla T_{\mathrm{q}}\right), \\
E_{\mathrm{q}}=h_{\mathrm{q}}-\frac{p}{p_{\mathrm{q}}}+\frac{v^{2}}{2},
\end{gathered}
$$

where $E_{\mathrm{q}}, h_{\mathrm{q}}, \rho_{\mathrm{q}}$ are the energy, enthalpy and density of $q$-phase water, respectively. The $q$-phase and enthalpy $h_{\mathrm{q}}$ can be represented by sensible enthalpy $h$ and enthalpy variation $\Delta H$ in the solidification and melting model, which is given by

$$
\begin{gathered}
h_{q}=h+\Delta H, \\
h=h_{r e f}+\int_{T_{\text {ref }}}^{T} c_{p} d T, \\
\Delta H=\beta L,
\end{gathered}
$$

where $h_{r e f}$ is the reference enthalpy, $T_{\text {ref }}$ is the reference temperature, $c_{p}$ is the specific heat, $L$ represents the latent heat of liquid water and $\beta$ is the volume fraction of the liquid which is expressed by

$$
\beta= \begin{cases}0 & T_{q}<T_{\text {solidus }} \\ \frac{T_{q}-T_{\text {solidus }}}{T_{\text {liquidus }}-T_{\text {solidus }}} & T_{\text {solidus }}<T_{q}<T_{\text {liquidus }}, \\ 1 & T_{q}>T_{\text {solidus }}\end{cases}
$$

where $T_{\text {solidus }}$ is the temperature at which water starts to freeze, $T_{\text {liquidus }}$ is the temperature at which liquid begins to melt, $K_{i}$ is the separation coefficient of solute $i$, which is the concentration ratio of the solid to liquid interface, $Y_{i}$ is the mass fraction of solute $i$ and $m_{i}$ is the liquid limit surface gradient after considering the $Y_{i}$. It is assumed that the last component of the mixture is a solvent and the other components are solutes.

(3) The energy equation of the porous media (such as gas diffusion layer, proton exchange membrane, and electrothermal membrane) in a PEMFC stack is as follows

$$
\frac{\partial}{\partial t}\left[\gamma \rho_{\mathrm{f}} E_{\mathrm{f}}+(1-\gamma) \rho_{\mathrm{s}} E_{\mathrm{s}}\right]=\nabla \cdot\left[k_{\mathrm{eff}} \nabla T_{\mathrm{fs}}-\left(\sum_{i} h_{i} \overrightarrow{j_{i}}\right)\right]+S_{\mathrm{h}}, k_{\mathrm{eff}}=\gamma k_{\mathrm{f}}+(1-\gamma) k_{\mathrm{s}}
$$

where the total energy of the fluid is defined as $E_{\mathrm{f}}$, the total energy of the solid medium is defined as $E_{\mathrm{s}}, \gamma$ is the porosity of the porous medium, $T_{\mathrm{fs}}$ is the temperature of the porous medium region, $S_{\mathrm{h}}$ is the source term, $k_{\text {eff }}$ is the effective thermal conductivity of the medium, $k_{\mathrm{f}}$ is the thermal conductivity of the liquid phase and $k_{\mathrm{s}}$ is the thermal conductivity of the solid phase.

All the above unit of variables are summarized in Appendix C.

\subsection{Numerical Implementations}

The commercial code ANSYS Fluent is used; all source terms of the governing equations $S$, thermal conductivity $K$, heat transfer convection coefficient, are calculated based on the study of electrothermal film [13]. Both the proton exchange membrane (PEM) and electrothermal film (ETF) of the volume power density are $1 \times 10^{7} \mathrm{~W} / \mathrm{m}^{3}$, the PEM thermal conductivity $\mathrm{K}$ is $0.18 \mathrm{~W} / \mathrm{m} \cdot \mathrm{K}$. The detailed calculation procedure about thermal power density and thermal conductivity is shown in Appendix $\mathrm{B}$. The heat transfer convection coefficient is shown in Figure 1 , where the $h_{\text {ext-up }}, h_{\text {ext-down }}, h_{\text {ext-left }}$, $h_{\text {ext-right }}$ represent the heat transfer convection coefficient in top side, bottom side, left sides and right sides of the PEMFC stack, respectively. The corresponding values are $7.16 \mathrm{~W} / \mathrm{m}^{3}, 3.58 \mathrm{~W} / \mathrm{m}^{3}$, $4.89 \mathrm{~W} / \mathrm{m}^{3}, 4.89 \mathrm{~W} / \mathrm{m}^{3}$, respectively. The detailed calculation process of the heat transfer convection coefficients are shown in Appendix A. 


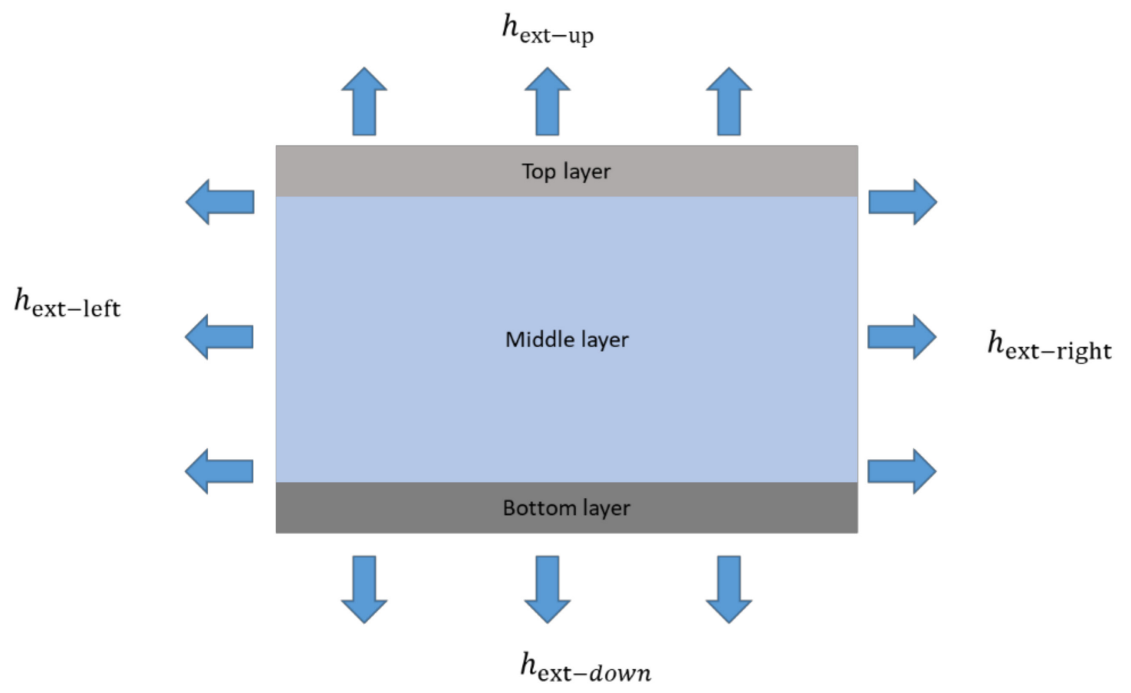

Figure 1. The boundary of a proton exchange membrane fuel cell (PEMFC).

A pressure-based solver is adopted, which employs an algorithm belonging to the general method category, called the projection method [33]. The detailed solving process is shown in Figure 2.

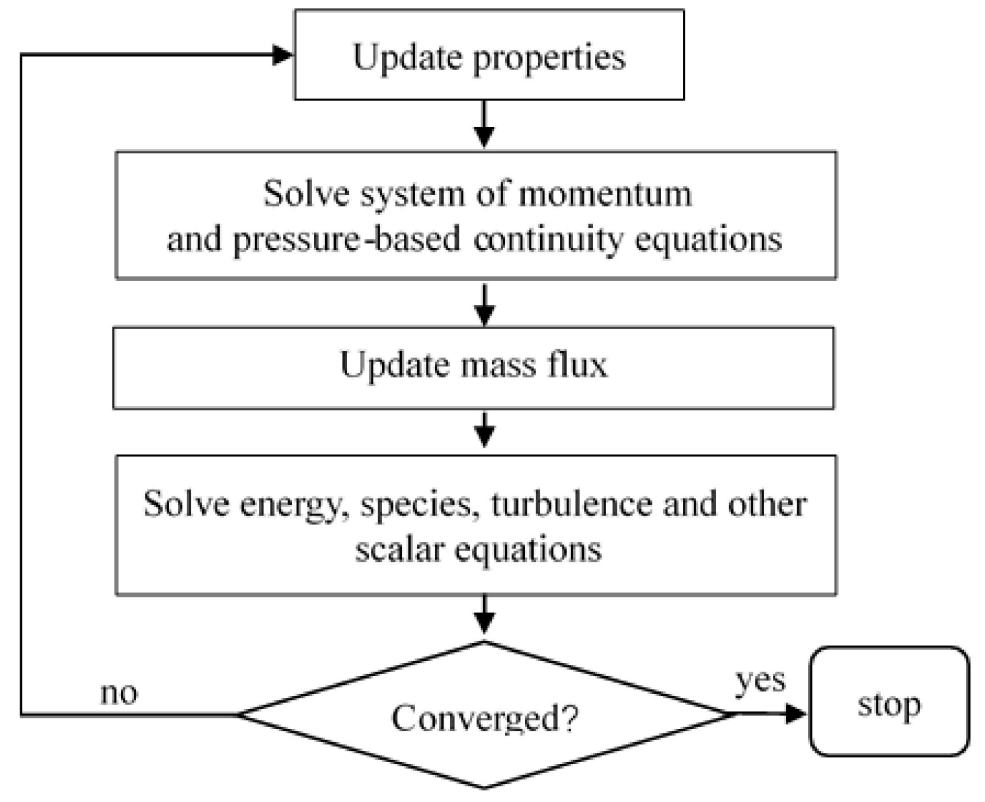

Figure 2. Pressure-based algorithm.

The pressure-implicit with splitting of operators (PISO) pressure-velocity coupling algorithm is utilized, which is based on the higher degree of the approximate relation between the corrections for pressure and velocity. In the iterative process, all the equations are solved for a given time-step, until the convergence criteria are met. The detailed iteration process is shown in Figure 3. 


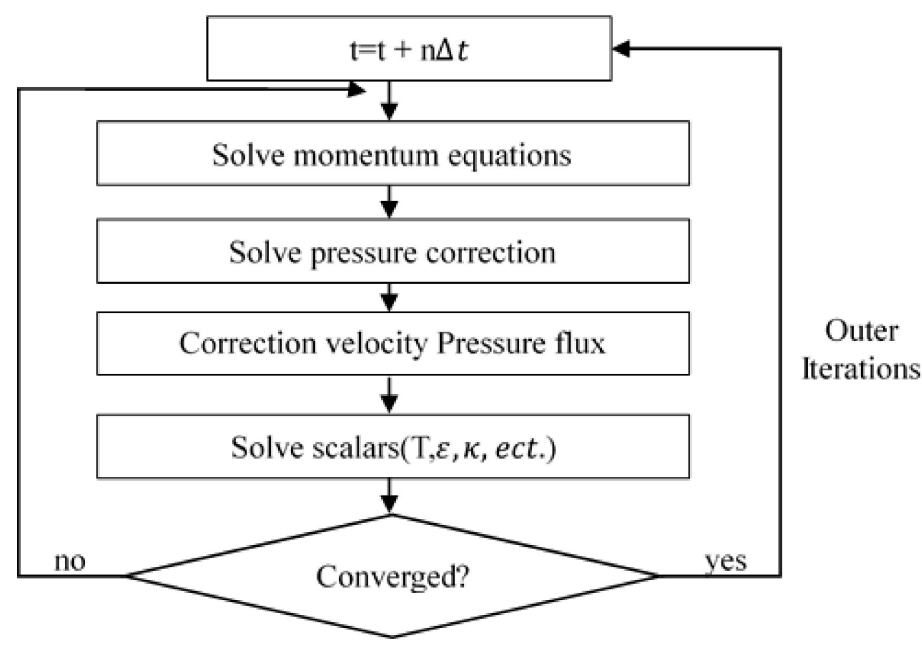

Figure 3. The pressure-implicit with splitting of operators (PISO) pressure-velocity coupling scheme.

\subsubsection{PEMFC Stack Geometries and Properties}

This paper establishes a two-dimensional PEMFC stack, which consists of 40 single PEMFCs connected in series. Each PEMFC consists of a cathode/anode bipolar plate (BP), a cathode/anode gas flow channel (GFC), a cathode/anode gas diffusion layer (GDL), a cathode/anode catalyst layer (CL), and a proton exchange membrane (PEM). The melting process of the ice is assumed to occur in the boundary area between the cathode/anode GFC and the GDL. The model structure of the PEMFC stack is shown in Figure 4, where the structure dimensions and material parameters are given in Table 1.

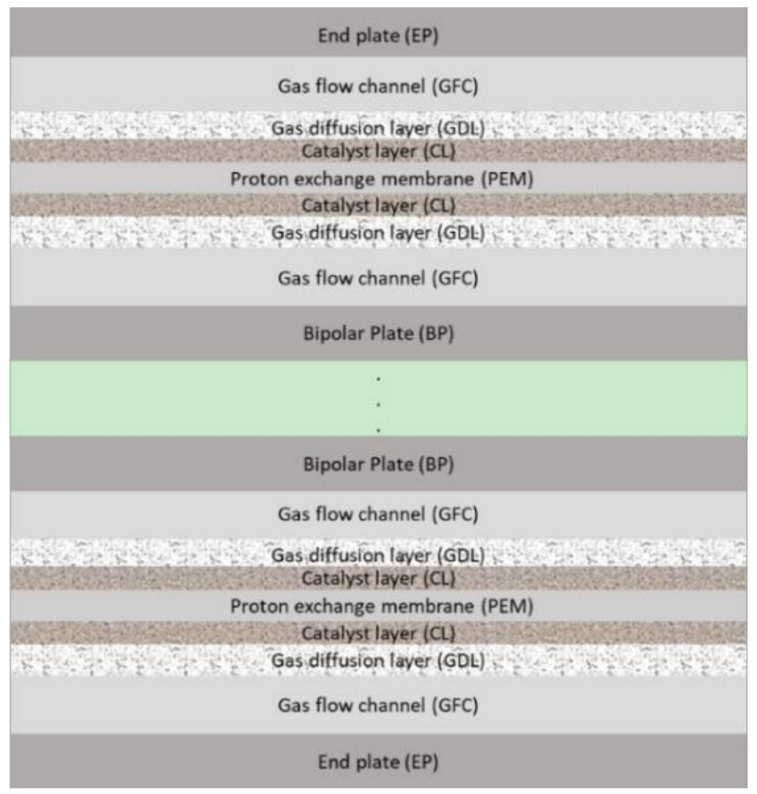

Figure 4. The structure of a PEMFC stack. 
Table 1. The structure dimensions and material parameters [34].

\begin{tabular}{|c|c|c|c|}
\hline Material & Parameters & Material & Parameters \\
\hline Density of GDL/(kg. $\left.\mathrm{m}^{-3}\right)$ & 2200 & Density of PEM $/\left(\mathrm{kg} \cdot \mathrm{m}^{-3}\right)$ & 1980 \\
\hline Specific heat capacity of GDL/(J.kg $\left.{ }^{-1} \cdot \mathrm{K}^{-1}\right)$ & 1050 & Specific heat capacity of PEM/(J.kg $\left.{ }^{-1} \cdot \mathrm{K}^{-1}\right)$ & 1050 \\
\hline Porosity of GDL & 0.5 & Porosity of PEM & 0.1 \\
\hline Densities of BP, GFC/(kg. $\left.\mathrm{m}^{-3}\right)$ & 1900 & Density of $\mathrm{CL} /\left(\mathrm{kg} \cdot \mathrm{m}^{-3}\right)$ & 2000 \\
\hline Density of water/(kg. $\left.\mathrm{m}^{-3}\right)$ & 998.2 & Reference temperature of liquid water/K & 298 \\
\hline Specific heat capacity of liquid water/(J.kg $\left.{ }^{-1} . \mathrm{K}^{-1}\right)$ & 4182 & Reference enthalpy of liquid water/(J. kg $\left.{ }^{-1} \cdot \mathrm{mol}^{-1}\right)$ & $-2.858 \times 10^{8}$ \\
\hline Thermal conductivity of liquid water/(W.m $\left.{ }^{-1} \cdot \mathrm{K}^{-1}\right)$ & 0.6 & Melting heat $/\left(\mathrm{J} \cdot \mathrm{kg}^{-1}\right)$ & 334,000 \\
\hline Solidus of liquid water/K & 273.15 & Liquidus of liquid water/K & 273.15 \\
\hline
\end{tabular}

\subsubsection{Meshing and Boundary}

Due to an existing large number of meshing points, Figure 5a only shows the computational mesh of two single PEMFCs, Figure $5 \mathrm{~b}$ shows the half of one single fuel cell meshing points. As a sufficient quantity of mesh is conducive to improve the calculation accuracy, several kinds of meshing size have been designed, which are $200 \mu \mathrm{m}, 100 \mu \mathrm{m}, 50 \mu \mathrm{m}, 40 \mu \mathrm{m}, 35 \mu \mathrm{m}, 30 \mu \mathrm{m}, 10 \mu \mathrm{m}$, respectively. We took ice melting time as the research object, and finally found that the meshing sizes of $200 \mu \mathrm{m}, 100 \mu \mathrm{m}$, and $50 \mu \mathrm{m}$ were quite different; the minimum difference between them reached up to $20 \%$, while the results for $40 \mu \mathrm{m}, 35 \mu \mathrm{m}, 30 \mu \mathrm{m}$, and $10 \mu \mathrm{m}$ were almost the same. We finally chose a meshing edge length of $40 \mu \mathrm{m}$ for improving calculation efficiency. In order to simplify the model and reduce the calculation time, 1/2 model is adopted and a geometric/symmetric condition is applied at the bottom surface of the PEMFC stack. On the other hand, convection heat transfer coefficient is used to the all external surfaces of the PEMFC stack, and the detailed boundary conditions are represented in Appendix A.

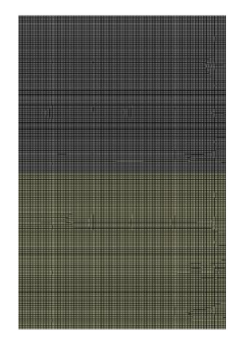

(a)
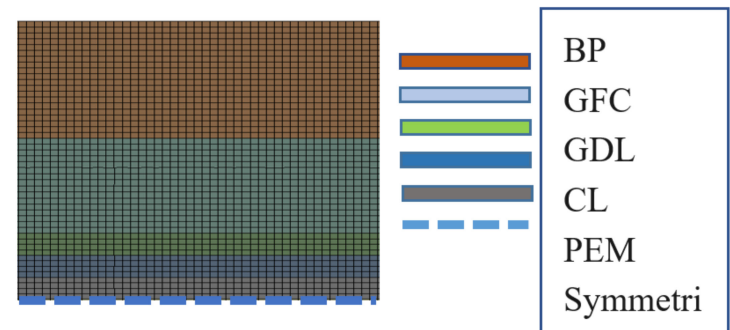

(b)

Figure 5. (a) The meshing points of two single PEMFCs. (b) The meshing points of half of one single PEMFC. 
The boundary conditions for the numerical simulation are as follows

$$
k \frac{\partial T_{w}}{\partial n}=h_{e x t}\left(T_{e x t}-T_{w}\right),
$$

where $k$ is the thermal conductivity of the material, $h_{\text {ext }}$ is the heat exchange coefficient of the outer surface of the material to air, $T_{\text {ext }}$ is the external ambient temperature, and $T_{w}$ is the outer surface temperature of the material.

\section{Results and Discussions}

\subsection{The Results of PEMFC Stack Heating with Proton Exchange Membrane}

The water in the gas flow channel (GFC) freezes easily. In order to study the melting process, the ice with a thickness of $0.1 \mathrm{~mm}$ is built on the gas flow channel. This part of the article takes the PEM as a heat source and applies a constant thermal power density of $1 \times 10^{7} \mathrm{~W} / \mathrm{m}^{3}$; the ambient temperature of $263 \mathrm{~K}$ is set to observe the ice melting process and calculating the melting time.

The average temperature distribution of the material center of each layer in the PEMFC stack at different times is given by Figure 6 . It can be seen that the temperature of each layer gradually increases with time, the proton exchange membrane (PEM) temperature is the highest, and the temperature of the catalyst layer (CL), gas diffusion layer (GDL), ICE, and gas flow channel (GFC) layers is relatively lower, and the temperature of the bipolar plate (BP) layer is the lowest. It is also apparent that when the temperature rises to $273 \mathrm{~K}$, the ice starts to melt and the complete melting time lasts for about $12 \mathrm{~s}$. Due to the fact that ice needs to absorb heat during the melting process, the temperature curvature of each layer is almost horizontal from the beginning to the end. After the ice is completely melted, the temperature of each layer continues to rise.

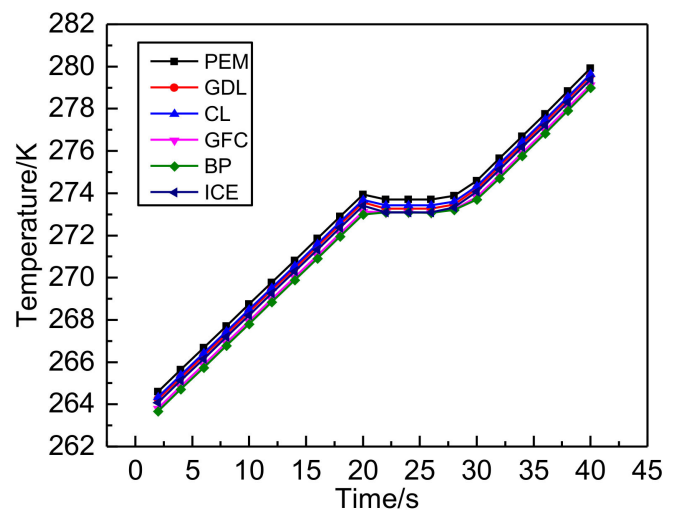

Figure 6. The average temperature distribution of each layer in the PEMFC stack.

The liquid fraction distribution at the center of the ICE layer in the PEMFC stack at different times is given by Figure 7, what can be seen from the figure is the fact that the liquid fraction is 0 before the temperature reaches $273 \mathrm{~K}$. When the temperature arrives at $273 \mathrm{~K}$ and the time is $20 \mathrm{~s}$, the ice starts to melt, and as the heating time increases, the liquid fraction of ice increases gradually. When it is heated to $32.5 \mathrm{~s}$, the liquid fraction is 1 , which means the ice is completely melted.

In order to observe the overall temperature distribution of the PEMFC Stack, the 16th second is selected to observe the temperature distribution in the vertical direction. The temperature distribution curve of each layer of the PEMFC stack before the overall temperature reached the melting point is displayed in Figure 8. The horizontal ordinate is the distance in the vertical direction of PEMFC stack, including the negative/positive GFC, the ICE, the GDL, the CL, the PEM, and the BP of fuel cell. In addition, the vertical coordinate is the temperature distribution in the vertical direction, it can be clearly seen that the temperature differentiates between the layers in the PEMFC stack. Among them, 
the average temperature of the BP is the lowest, only $270.5 \mathrm{~K}$, the PEM is the highest, $271.6 \mathrm{~K}$, and GFC is $271.5 \mathrm{~K}$.

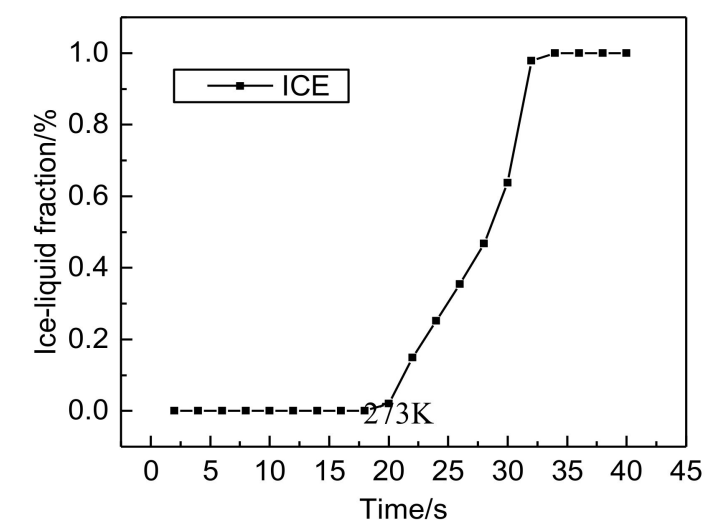

Figure 7. The liquid fraction distribution of the ICE layer in the PEMFC stack.

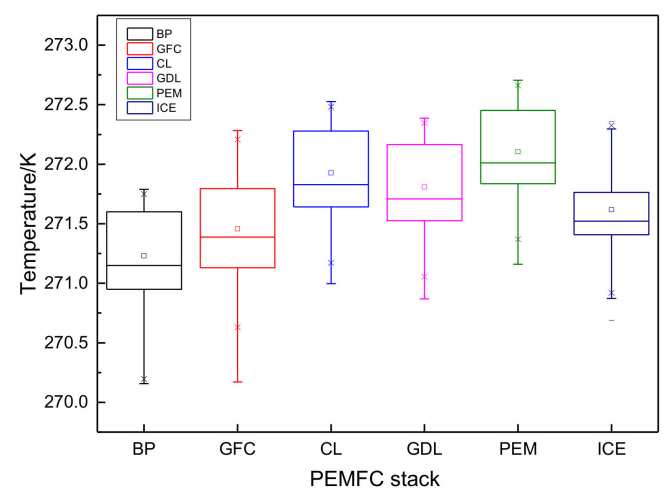

Figure 8. The temperature distribution in the vertical direction at 16 th second.

The temperature distribution of the PEMFC stack at different times ( $24 \mathrm{~s}, 28 \mathrm{~s}, 32 \mathrm{~s})$ is shown in Figure 9. The ice is located at the middle of the blue area because there is no ice on the edges where the temperature is higher. The temperature distribution of the ice inside is still lower, and the temperature reaches a melting point of $273 \mathrm{~K}$ at $24 \mathrm{~s}$. As the heating time increases, the temperature continues to rise and the ice continues to melt. Figure 10 shows the temperature distribution of PEM at different times (24 s, 28 s, $32 \mathrm{~s}$ ), which can be seen clearly that the temperature gradually increases as computing time extension.

Figure 11 depicts the melting process of the PEMFC stack at different times (24 s, $28 \mathrm{~s}, 32 \mathrm{~s})$, showing that the temperature of the PEMFC stack reaches $273 \mathrm{~K}$ at $24 \mathrm{~s}$, and the ice in PEMFC stack begins to melt. The inner ice melts first and the first and 40th pieces melt last. Most of the ice in the PEMFC stack melts at $28 \mathrm{~s}$, and the ice is basically melted at $32 \mathrm{~s}$. Figure 12 shows the melting process of the ice at different times (24 s, 28 s, 32 s); it can be seen that the ice in the PEMFC stack begins to melt at $24 \mathrm{~s}$, and most of the ice in the PEMFC stack melts at $28 \mathrm{~s}$, and the ice is basically melted at $32 \mathrm{~s}$. The reason why only the top layer is not completely melted is because the top layer cell is in direct contact with the atmosphere, where there exists a natural convective heat dissipation. The complete melting time of ice is $32.5 \mathrm{~s}$. 


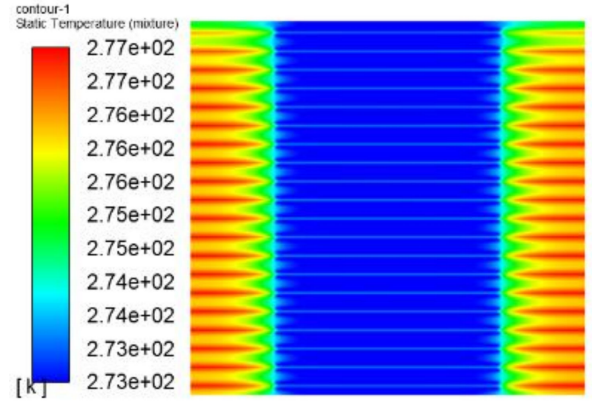

(a)

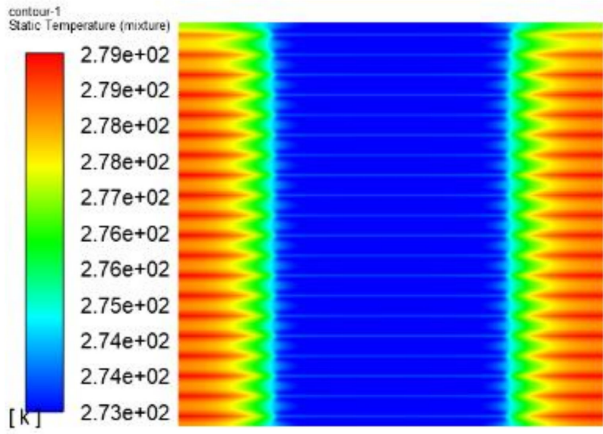

(b)

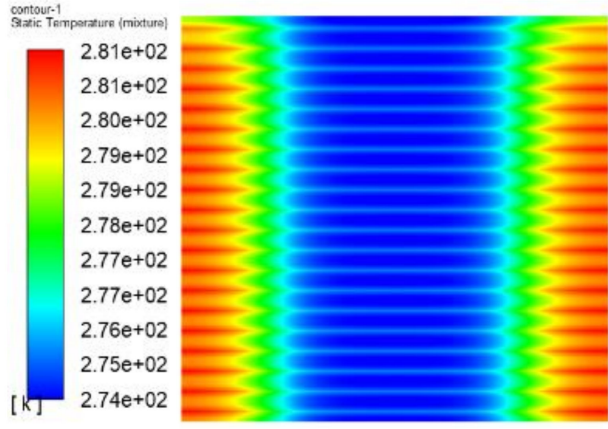

(c)

Figure 9. Temperature contours of the PEMFC stack at different times: $(\mathbf{a}) t=24 \mathrm{~s},(\mathbf{b}) \mathrm{t}=28 \mathrm{~s},(\mathbf{c}) \mathrm{t}=32 \mathrm{~s}$.

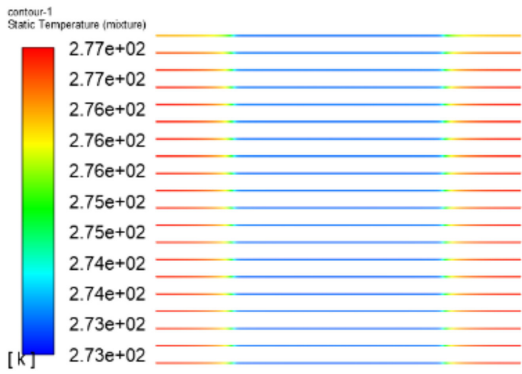

(a)

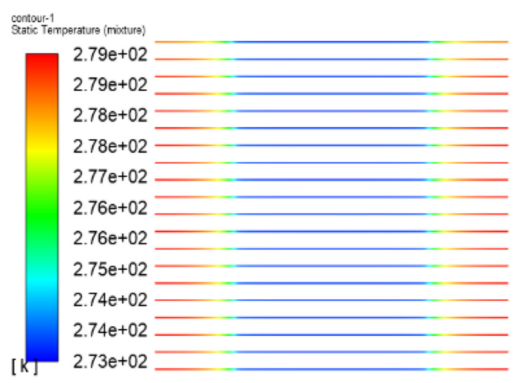

(b)

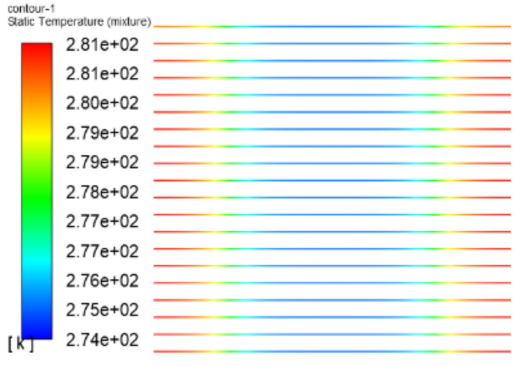

(c)

Figure 10. Temperature contours of the PEM at different times; $(a) t=24 s,(b) t=28 s,(c) t=32 s$. 


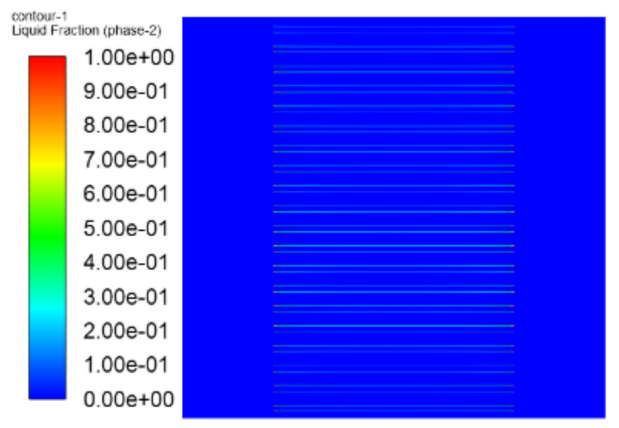

(a)

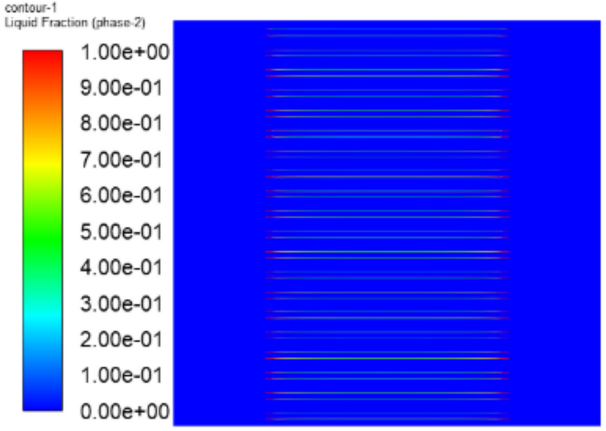

(b)

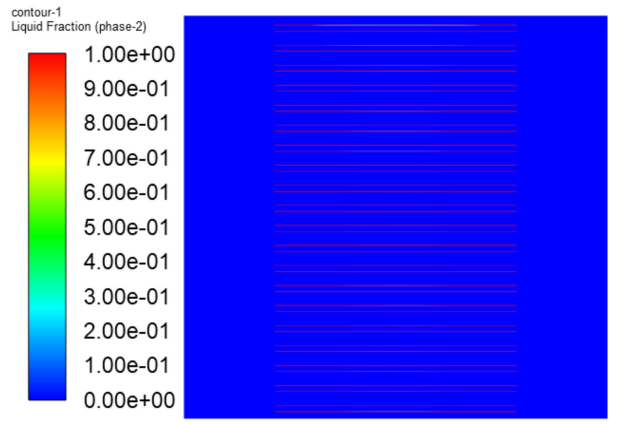

(c)

Figure 11. Liquid fraction contours of the PEMFC stack at different times; (a) $t=24 s,(b) t=28 s,(c) t=32 s$.

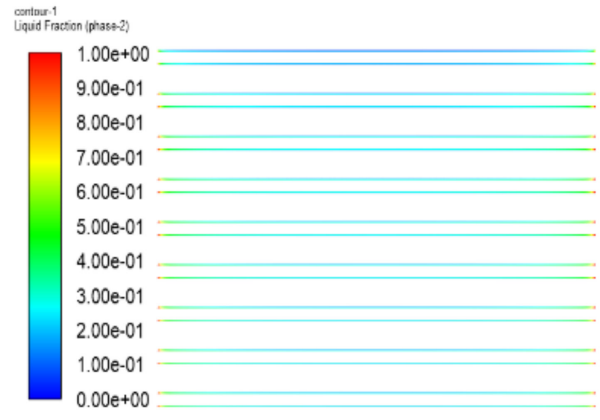

(a)

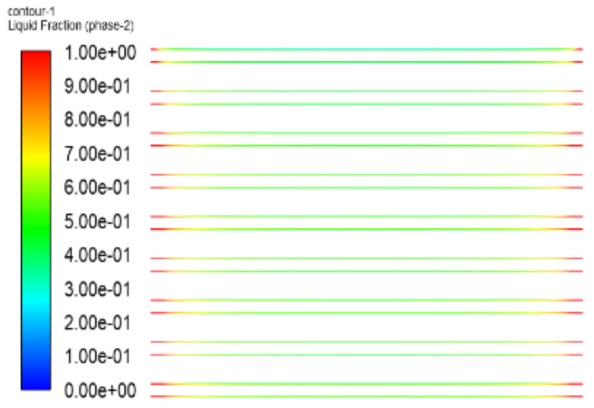

(b)

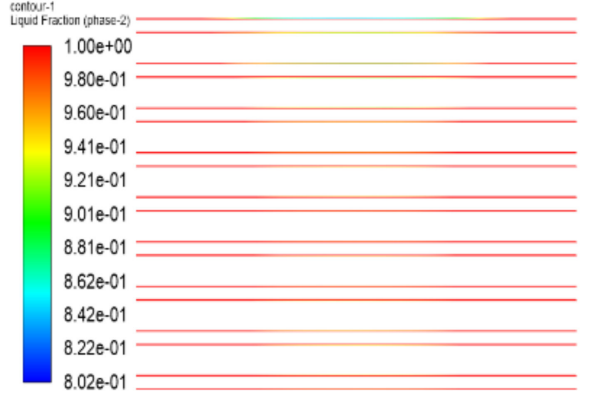

(c)

Figure 12. Liquid fraction contours of the ice at different times; $(\mathbf{a}) t=24 \mathrm{~s},(\mathbf{b}) t=28 \mathrm{~s},(\mathbf{c}) t=32 \mathrm{~s}$. 


\subsection{The Results of PEMFC Stack Heating with Electrothermal Film}

In order to study the melting process and the ice melting time, the ice with a thickness of $0.1 \mathrm{~mm}$ is established on the Gas Flow Channel, and the Electrothermal Film (ETF) with a thickness of $0.1 \mathrm{~mm}$ is built on the ice. This part of the article takes the ETF as a heat source and sets a constant thermal power density and ambient temperature as $1 \times 10^{7} \mathrm{~W} / \mathrm{m} \mathrm{C}, 263 \mathrm{~K}$, respectively.

Figure 13 is the average temperature distribution of the material center of each layer in the PEMFC stack at different times. It can be seen that the temperature of each layer gradually increases with time, the ETF temperature is the highest, the temperatures of GDL, CL, PEM, ICE, and GFC layers are relatively lower, and the $\mathrm{BP}$ layer has the lowest temperature. What we can also conclude is that when the temperature rises to $273 \mathrm{~K}$, the ice starts to melt, and the whole melting time lasts for about $15 \mathrm{~s}$. From the beginning to the end of the melting, the temperature curvature of each layer is small. This is due to the reason that the ice needs to absorb heat during the melting process. After the ice has completely melted, the temperature of each layer continues to rise.

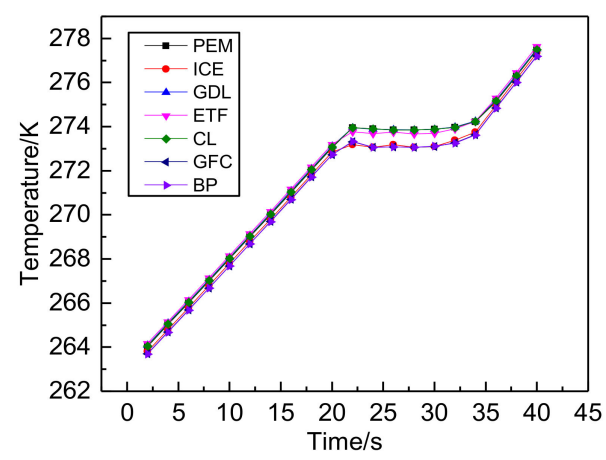

Figure 13. The average temperature distribution of each layer in the PEMFC stack.

The liquid fraction distribution of the center of the ICE layer in the inner layer fuel cell of the PEMFC stack at different times is given by Figure 14, from which it can be seen that the liquid fraction is 0 before the temperature reaches $273 \mathrm{~K}$. When the temperature arrives at $273 \mathrm{~K}$ and the time is $20 \mathrm{~s}$, the ice starts to melt. As the heating time increases, the liquid fraction of ice gradually rises. When it is heated to $36 \mathrm{~s}$, the liquid fraction is 1 and the ice is completely melted.

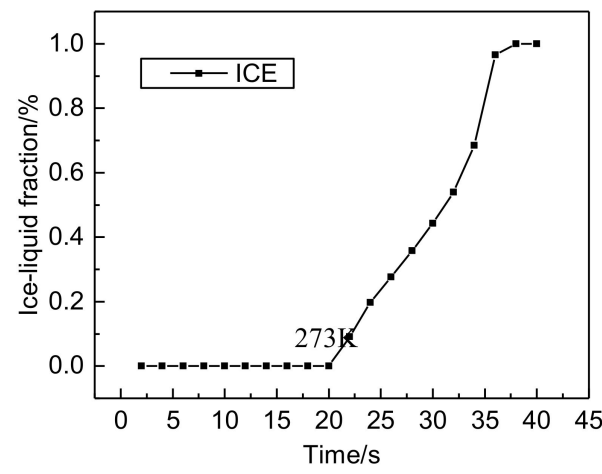

Figure 14. The liquid fraction distribution of the ICE layer in the PEMFC stack.

In order to observe the overall temperature distribution of the PEMFC Stack, the 16th second is selected to observe the temperature distribution in the vertical direction. Figure 15 is the temperature distribution curve of each layer of the PEMFC stack before the overall temperature reaches the melting point. The horizontal ordinate is the distance in the vertical direction of the PEMFC stack, including the negative/positive GFC, the ICE, the ETF, the GDL, the CL, the PEM, and the BP of the fuel cell, and the vertical coordinate is the temperature distribution in the vertical direction; the temperature differences 
between the layers in the PEMFC stack can be clearly seen. Among them, the average temperature of the $\mathrm{BP}$ is the lowest, only $270.05 \mathrm{~K}$, the ETF is the highest, $271.3 \mathrm{~K}$, and the GFC is $271.1 \mathrm{~K}$.

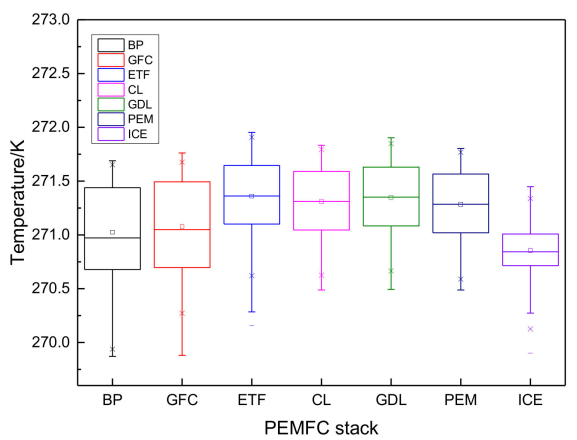

Figure 15. The temperature distribution in the vertical direction at 16 th second.

The temperature distribution of the PEMFC stack at different times (24 s, 32 s, 36 s) is shown in Figure 16. The ice is located at the middle of the blue area. Because there is no ice on the edges, the temperature is higher. However, the temperature distribution of the ice inside is still lower, and the temperature reaches the melting point of $273 \mathrm{~K}$ at $24 \mathrm{~s}$. As the heating time increases, the temperature continues to rise and the ice continues to melt. Figure 17 shows the temperature distribution of ETF at different times ( $24 \mathrm{~s}, 32 \mathrm{~s}, 36 \mathrm{~s}$ ), from which it can be seen clearly that the temperature gradually increases as computing time extends.

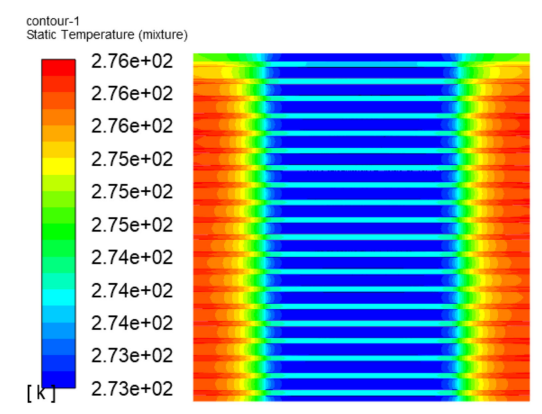

(a)

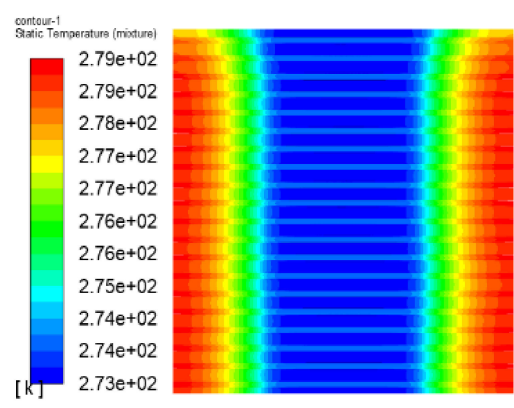

(b)

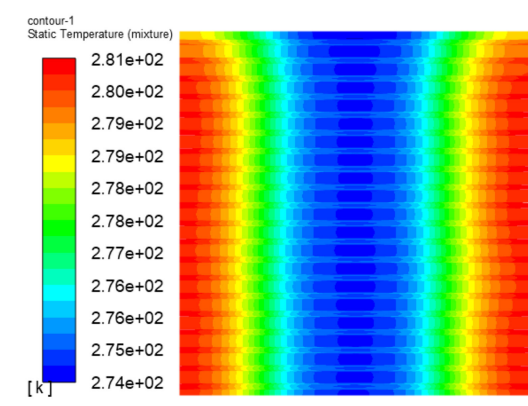

(c)

Figure 16. Temperature contours of the PEMFC stack at different times; $(\mathbf{a}) t=24 \mathrm{~s},(\mathbf{b}) \mathrm{t}=32 \mathrm{~s},(\mathbf{c}) \mathrm{t}=36 \mathrm{~s}$.

Figure 18 shows the melting process of the PEMFC stack at different times ( $24 \mathrm{~s}, 32 \mathrm{~s}, 36 \mathrm{~s})$, showing that the temperature of the PEMFC stack reaches $273 \mathrm{~K}$ at 24 , and the ice in the PEMFC stack begins to melt. The inner ice melts first and the first and 40th pieces melt last. Most of the ice in PEMFC stack melts at $32 \mathrm{~s}$, and the ice basically melts completely at $36 \mathrm{~s}$. Figure 19 shows the melting process of the ice at different times (24 s, $32 \mathrm{~s}, 36 \mathrm{~s})$, from which it can be seen that the ice in the PEMFC stack begins 
to melt at $24 \mathrm{~s}$, most of the ice in PEMFC stack melts at $32 \mathrm{~s}$, and the ice is basically melted at $36 \mathrm{~s}$. The reason why only the top layer is not completely melted is due to the fact that the top layer cell is in direct contact with the atmosphere and there is a natural convective heat dissipation. The complete melting time of ice is $36.5 \mathrm{~s}$.

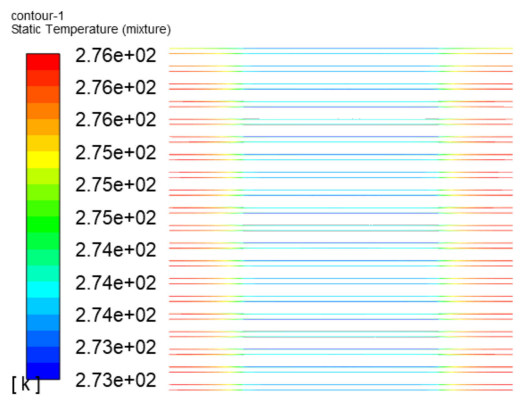

(a)

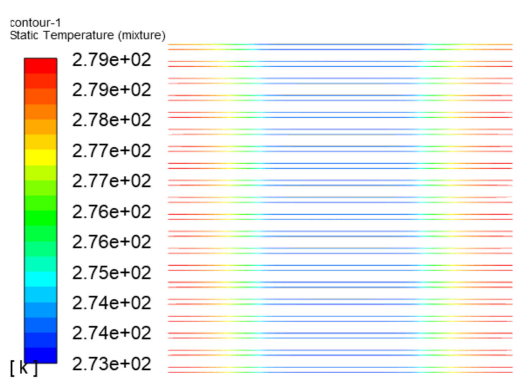

(b)

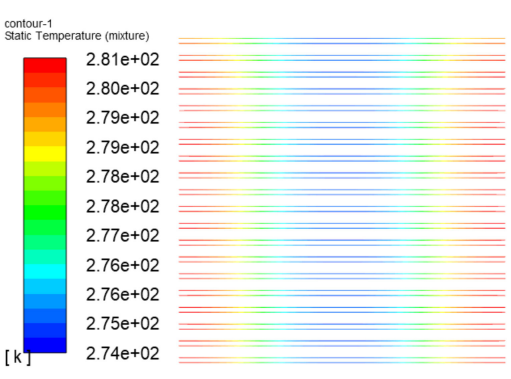

(c)

Figure 17. Temperature contours of the ETF at different times; $(\mathbf{a}) t=24 \mathrm{~s},(\mathbf{b}) t=32 \mathrm{~s},(\mathbf{c}) \mathrm{t}=36 \mathrm{~s}$.

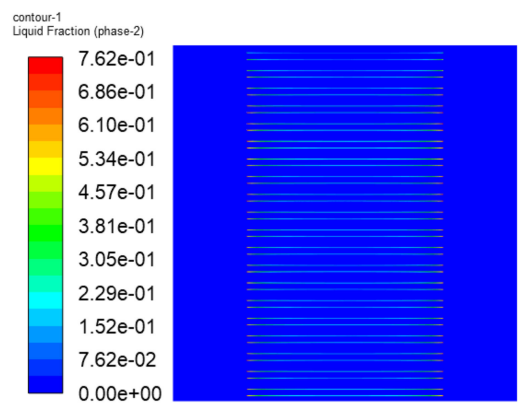

(a)

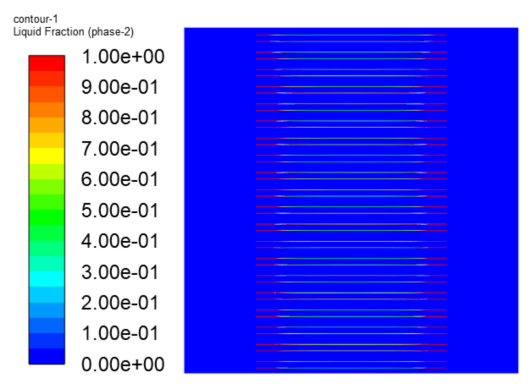

(b)

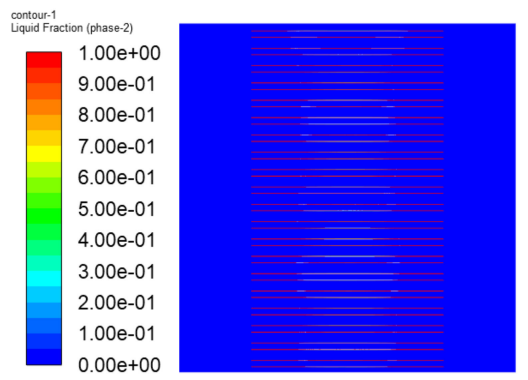

(c)

Figure 18. Liquid fraction contours of the PEMFC stack at different times; (a) $t=24 s,(b) t=32 s,(c) t=36 s$. 


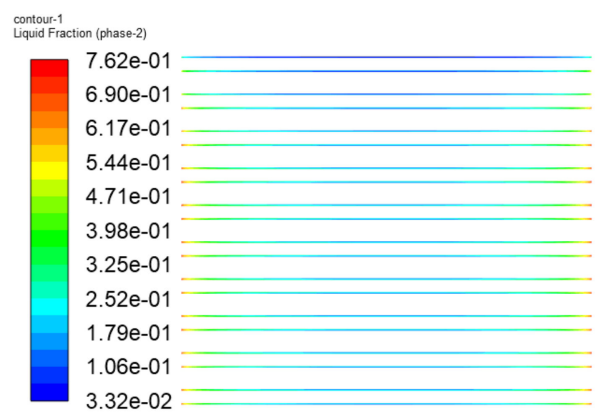

(a)

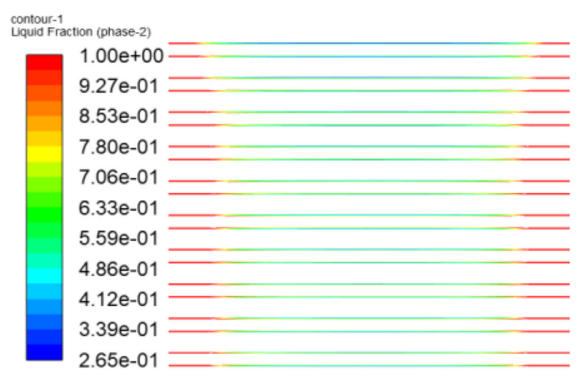

(b)

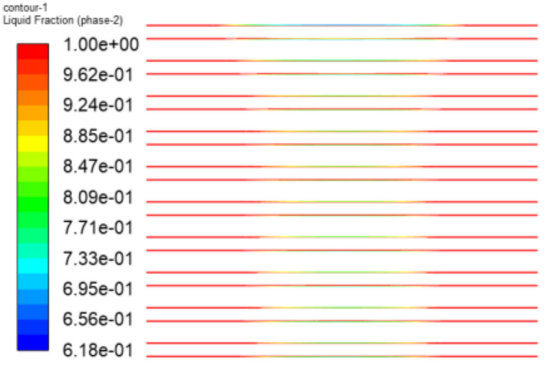

(c)

Figure 19. Liquid fraction contours of ice at different times; (a) $t=24 s,(b) t=32 s,(c) t=36 s$.

\subsection{The Simulation Results of Different Electrothermal Film Structure}

\subsubsection{The Three-Dimensional Structure Design of Electrothermal Film}

In order to ensure the smooth flow of hydrogen and air, the electrothermal film (ETF) should maintain a certain porosity. The effects of the different ETF structures on the melting time are researched. The structure adopts the same porosity, and ETF with different pore sizes are established. Due to comparative analysis, this paper only builds one fuel cell. The structure is the GFC, ICE, and ETF from the bottom to the top. In order to simplify the model, only one half of a fuel cell is built and symmetric constraints are applied on the top face of the GFC. The dimension of the GFC is $40 \mathrm{~mm} \times 40 \mathrm{~mm} \times 1.6 \mathrm{~mm}$, both the ICE thickness and ETF thickness is $1 \mathrm{~mm}$. In this paper, a constant porosity of $60 \%$ is adopted, and the pore sizes from small to large are $0.3 \mathrm{~mm}, 0.6 \mathrm{~mm}$ and $1.2 \mathrm{~mm}$, respectively. A constant power density of $1 \times 10^{7} \mathrm{~W} / \mathrm{m}^{3}$ is used, and ambient temperature is set as $263 \mathrm{~K}$. The detailed fuel cell structure is shown in Figure 20, and the ETF structure is shown in Figure 21.

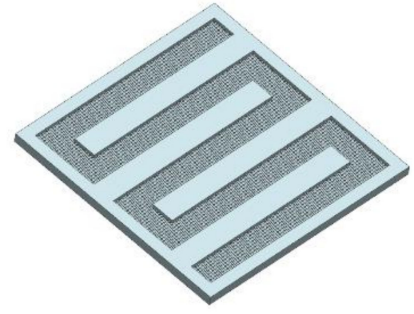

(a)

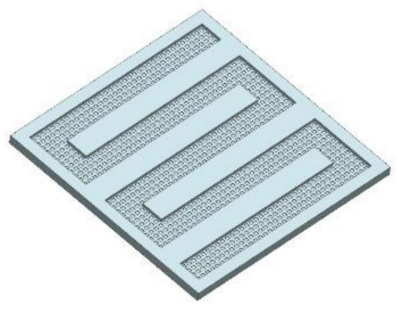

(b)

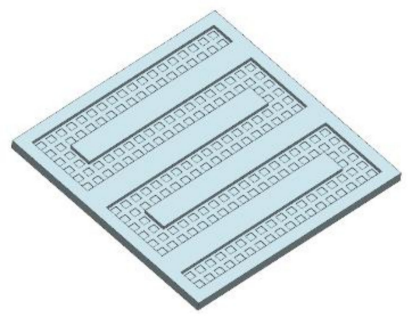

(c)

Figure 20. The three-dimensional structure of the half of fuel cell $((\mathbf{a})$ pore size $=0.3 \mathrm{~mm}$, (b) pore size $=0.6 \mathrm{~mm}$, (c) pore size $=1.2 \mathrm{~mm}$ ). 


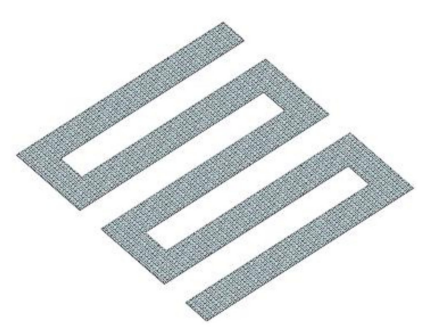

(a)

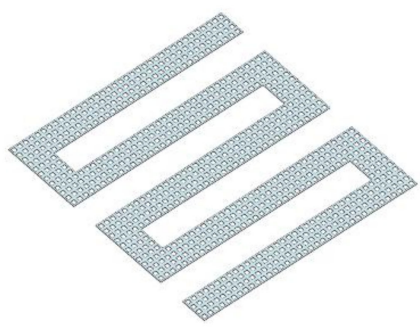

(b)

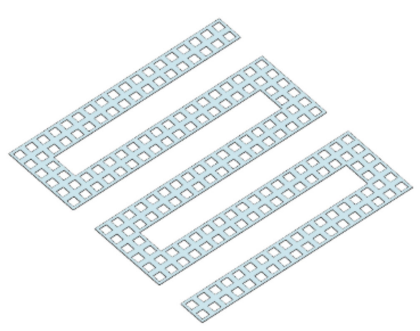

(c)

Figure 21. The three-dimensional structure of electrothermal film $((\mathbf{a})$ pore size $=0.3 \mathrm{~mm}$, $(\mathbf{b})$ pore size $=0.6 \mathrm{~mm}$, (c) pore size $=1.2 \mathrm{~mm}$ ).

\subsubsection{Simulation Results}

Figure 22 shows the process of the average temperature of each layer of ETF with different pore sizes over time; it can be seen that as the time increases, the temperature of each layer gradually increases, where the temperature of the ETF layer is the highest. The ICE layer is second and the GFC layer is the lowest. It can also be seen that when the temperature rises to $273 \mathrm{~K}$, the ice starts to melt, and the complete melting time lasts for about $10 \mathrm{~s}$. From the beginning to the end of the melting, the temperature curvature of each layer is small. This is because the ice needs to absorb heat during the melting process. After the ice has been completely melted, the temperature of each layer continues to rise. The lower right corner is an enlarged average temperature value of each layer of different ETF pore sizes at $46 \mathrm{~s}$. It can be clearly seen that at the same porosity, the ETF with a hole size of $0.3 \mathrm{~mm}$ has the higher temperature compared to the ETF with a 0.6- $\mathrm{mm}$ hole size. The temperature of $1.2 \mathrm{~mm}$ is the lowest.

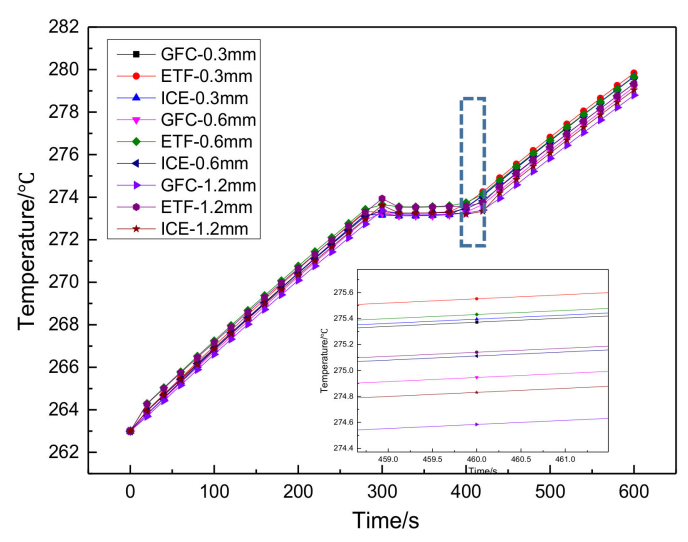

Figure 22. Average temperature of each layer of ETF with different pore sizes.

Figure 23 shows the liquid fraction distribution of different ETF structures at different times: the liquid fraction is shown to be 0 before the temperature reaches $273 \mathrm{~K}$. When the temperature reaches $273 \mathrm{~K}$, the ice starts to melt. As the heating time increases, the liquid fraction of the ice gradually increases. When the liquid fraction reaches 1 , the ice is completely melted. It can also be seen clearly is that the complete melting time of the ETF with different pore sizes is variable. The ETF with a pore size of $0.3 \mathrm{~mm}$ melts first, followed by $0.6 \mathrm{~mm}$, and $0.9 \mathrm{~mm}$ melts last. The complete melting times are $42 \mathrm{~s}, 44 \mathrm{~s}$, and $46 \mathrm{~s}$, respectively. 


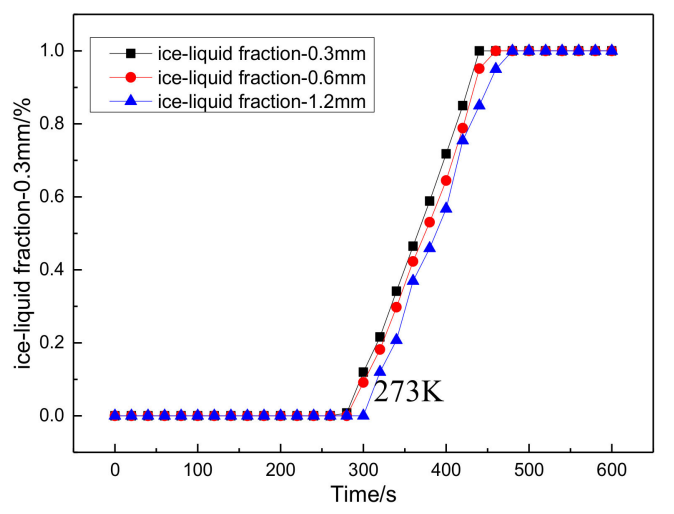

Figure 23. Liquid fraction distribution of different ETF structures at different times.

Figures 24-26 show the overall temperature distribution of the ETF with pore dimensions of $0.3 \mathrm{~mm}, 0.6 \mathrm{~mm}$ and $1.2 \mathrm{~mm}$, respectively. It can be seen that the ETF pore sizes of $0.3 \mathrm{~mm}, 0.6 \mathrm{~mm}$ and $1.2 \mathrm{~mm}$ arrive at the melting point after $28 \mathrm{~s}, 30 \mathrm{~s}$ and $32 \mathrm{~s}$, respectively. The final temperature of the PEMFC fuel cell is about $276 \mathrm{~K}$ when the ice is completely melted.

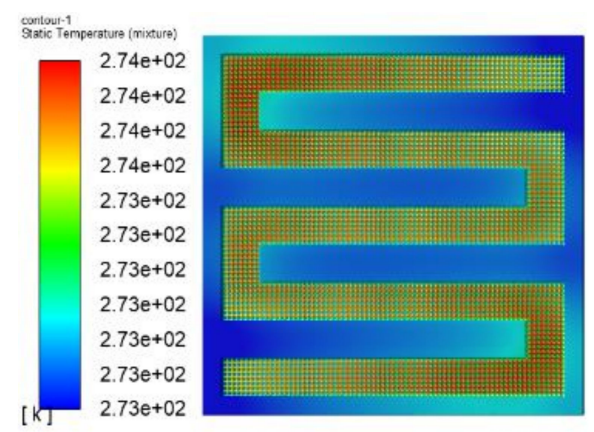

(a)

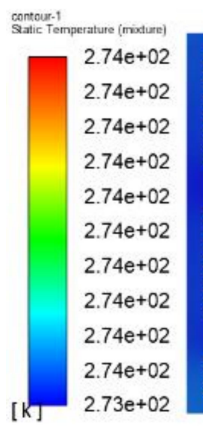

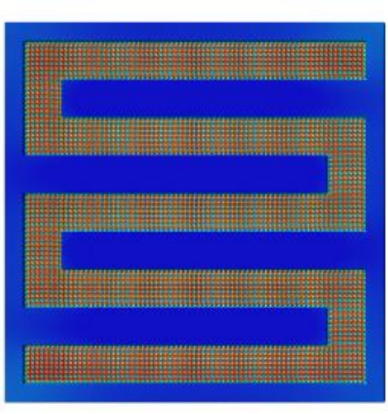

(b)

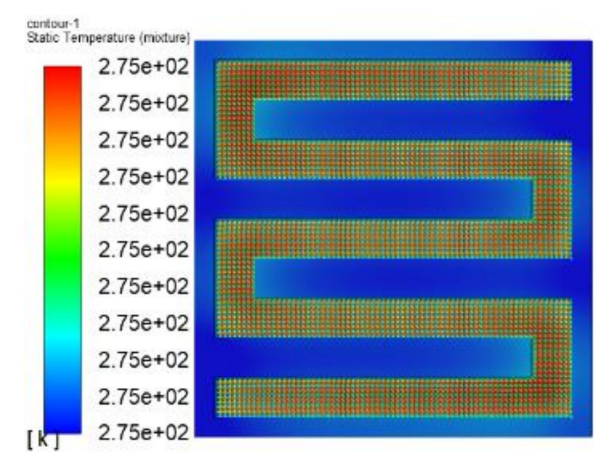

(c)

Figure 24. The fuel cell temperature contours with pore diameter $=0.3 \mathrm{~mm}$ at different times; $(\mathbf{a}) \mathrm{t}=28 \mathrm{~s}$, (b) $\mathrm{t}=40 \mathrm{~s},(\mathbf{c}) \mathrm{t}=44 \mathrm{~s}$.

Figures 27-29 shows the distribution of liquid fraction of ice when the hole sizes of the ETF are $0.3 \mathrm{~mm}, 0.6 \mathrm{~mm}$ and $1.2 \mathrm{~mm}$, respectively. It can be seen that the pore size of $0.3 \mathrm{~mm}$ melts first, followed by $0.6 \mathrm{~mm}$, and $1.2 \mathrm{~mm}$ is the last to completely melt. When the pore sizes of the ETF are $0.3 \mathrm{~mm}, 0.6 \mathrm{~mm}$ and $1.2 \mathrm{~mm}$, the ice initial melting times are $28 \mathrm{~s}, 30 \mathrm{~s}$ and $32 \mathrm{~s}$, respectively. The final melting times are $44 \mathrm{~s}, 46 \mathrm{~s}$ and $48 \mathrm{~s}$, respectively. 


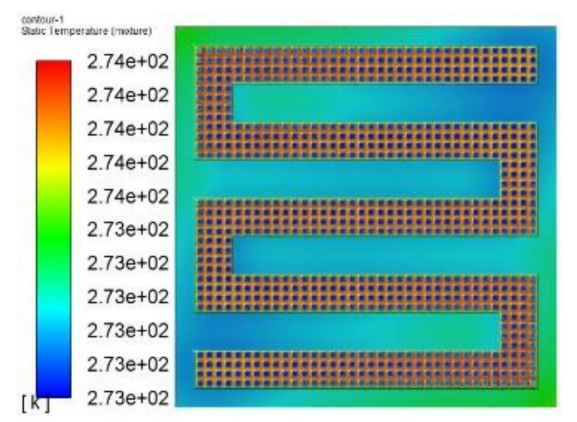

(a)

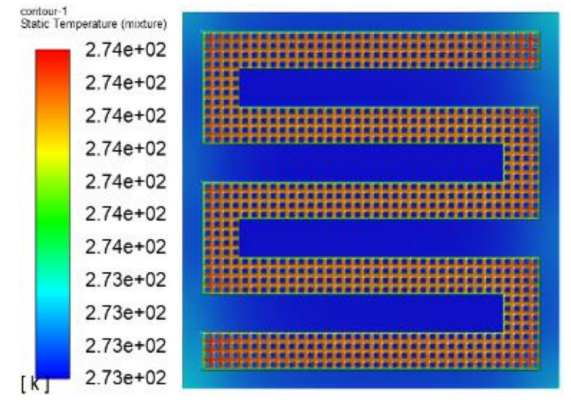

(b)

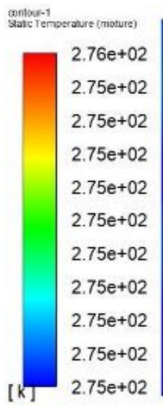

$76 e+02$
$75 e+02$
$75 e+02$
$75 e+02$
$75 e+02$
$75 e+02$
$75 e+02$
$75 e+02$
$75 e+02$
$75 e+02$
$75 e+02$

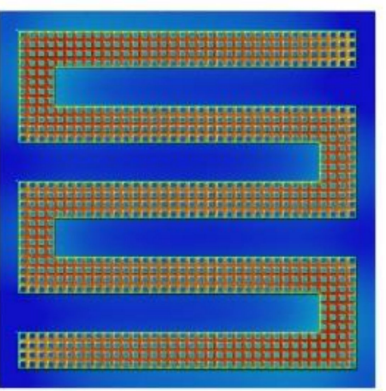

(c)

Figure 25. The fuel cell temperature contours with pore diameter $=0.6 \mathrm{~mm}$ at different times; $(\mathbf{a}) \mathrm{t}=30 \mathrm{~s}$, (b) $\mathrm{t}=38 \mathrm{~s}$, (c) $\mathrm{t}=46 \mathrm{~s}$.
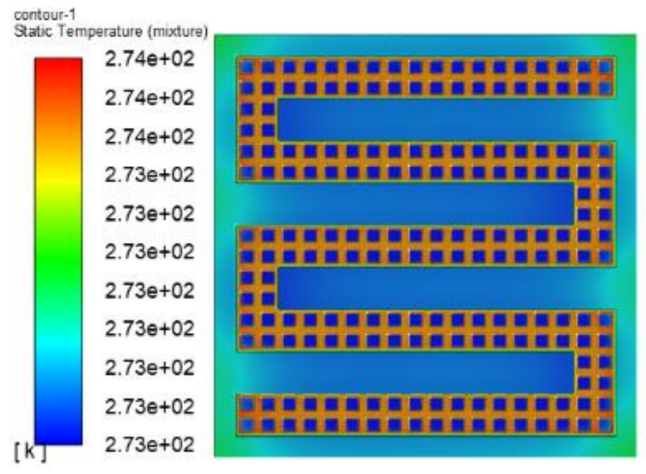

(a)
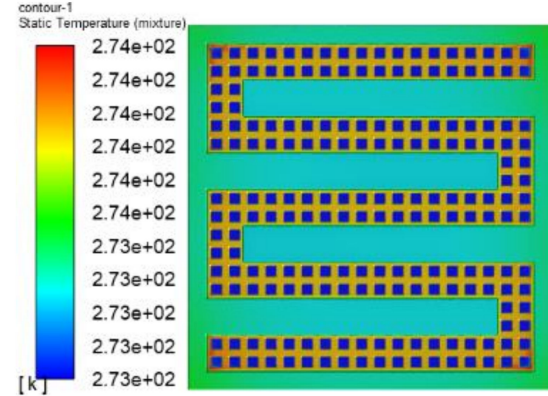

(b)

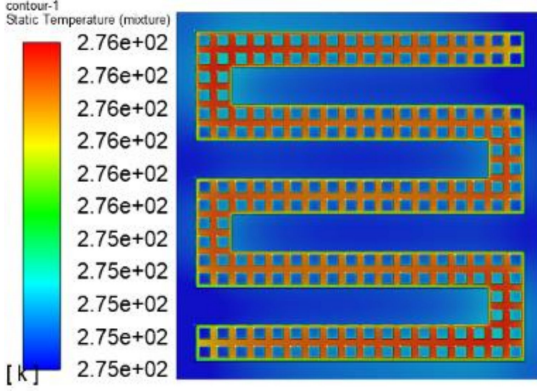

(c)

Figure 26. The fuel cell temperature contours with pore diameter $=1.2 \mathrm{~mm}$ at different times; $(\mathbf{a}) \mathrm{t}=32 \mathrm{~s}$, (b) $\mathrm{t}=42 \mathrm{~s}$, (c) $\mathrm{t}=48 \mathrm{~s}$. 


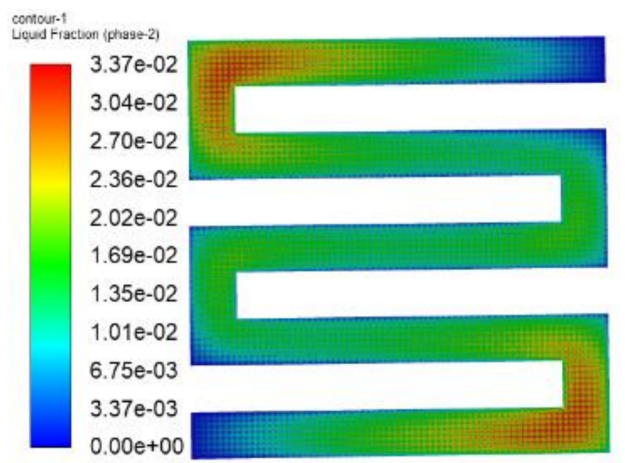

(a)

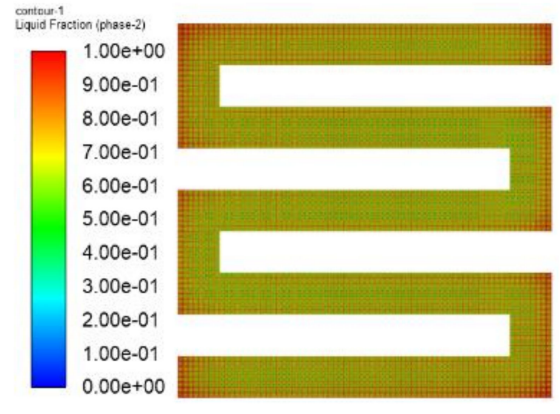

(b)

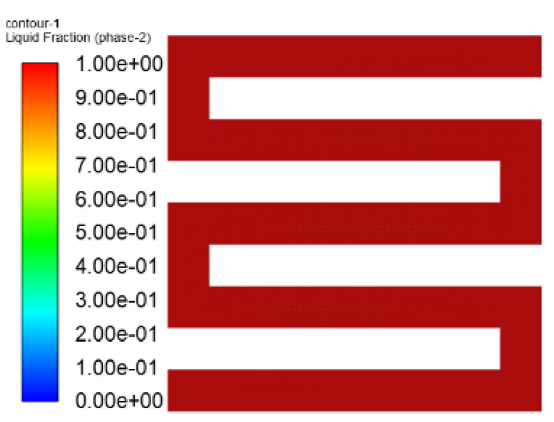

(c)

Figure 27. The fuel cell temperature contours with pore diameter $=0.3 \mathrm{~mm}$ at different times; $(\mathbf{a}) \mathrm{t}=28 \mathrm{~s},(\mathbf{b}) \mathrm{t}=40 \mathrm{~s}$, (c) $\mathrm{t}=44 \mathrm{~s}$.

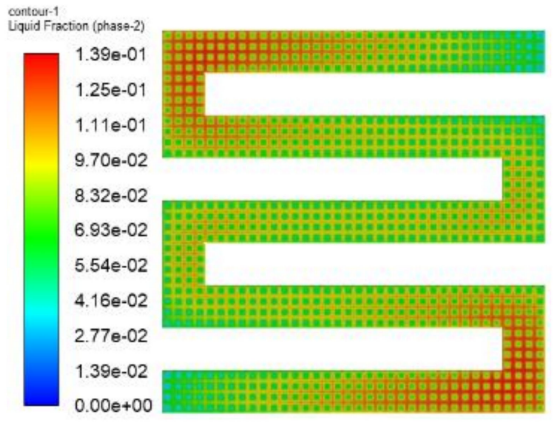

(a)

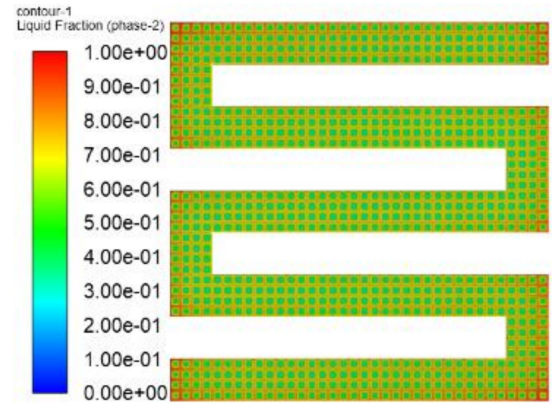

(b)

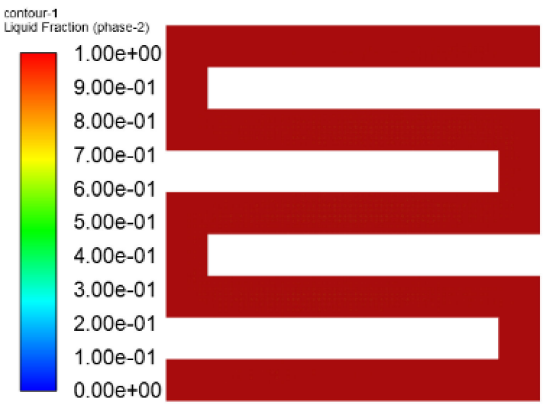

(c)

Figure 28. The fuel cell temperature contours with pore diameter $=0.6 \mathrm{~mm}$ at different times; $(\mathbf{a}) \mathrm{t}=30 \mathrm{~s}$, (b) $\mathrm{t}=38 \mathrm{~s},(\mathbf{c}) \mathrm{t}=46 \mathrm{~s}$. 


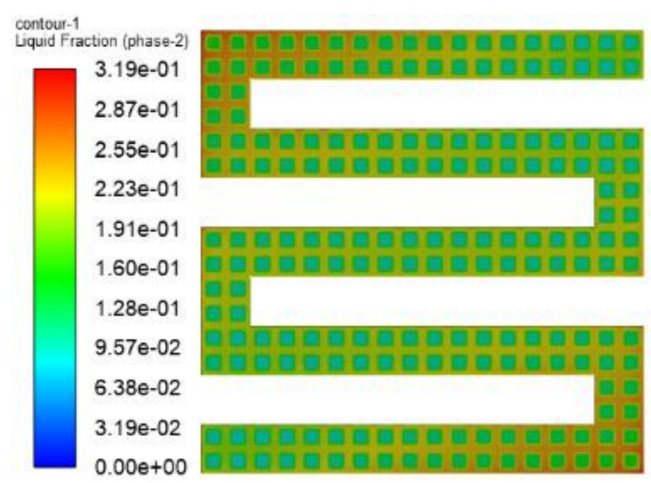

(a)

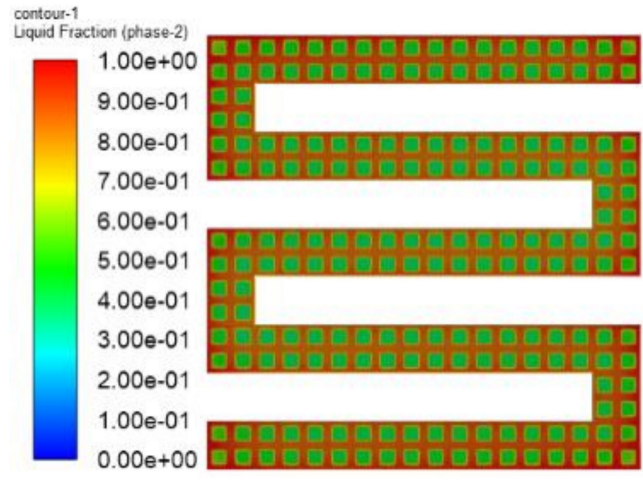

(b)

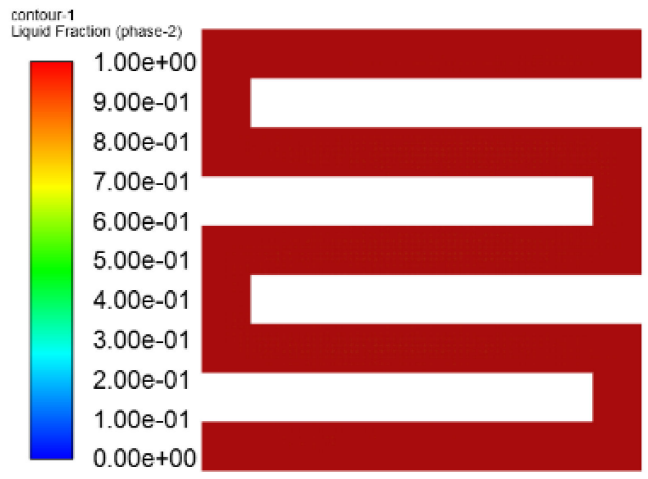

(c)

Figure 29. The fuel cell temperature contours with pore diameter $=1.2 \mathrm{~mm}$ at different times; $(\mathbf{a}) \mathrm{t}=32 \mathrm{~s}$, (b) $\mathrm{t}=42 \mathrm{~s}$, (c) $\mathrm{t}=48 \mathrm{~s}$.

\section{Conclusions}

Based on the solidification and melting model and multi-phase flow model, this paper applies the Fluent software to simulate the melting process of the PEMFC stack. The numerical simulation analysis of the melting process is conducted using the PEM electric heating method and the electrothermal film heating method. The following conclusions were obtained:

1. Both the PEM electric heating method and the electrothermal film heating method were able to achieve rapid cold start-up. The ice inside the PEMFC stack melted first, and the first and 40th pieces melted afterwards. The ice melting time of the PEMFC stack of the two methods was $32.5 \mathrm{~s}$ and $36.5 \mathrm{~s}$, respectively.

2. In order to study the effect of different electrothermal film (ETF) structures on cold start-up performance, ETFs with pore diameters of $0.3 \mathrm{~mm}, 0.6 \mathrm{~mm}$, and $0.9 \mathrm{~mm}$ were established. It was found that the pore size of $0.3 \mathrm{~mm}$ melts first, followed by $0.6 \mathrm{~mm}$, and then $1.2 \mathrm{~mm}$. When the pore sizes of the ETF were $0.3 \mathrm{~mm}, 0.6 \mathrm{~mm}$ and $1.2 \mathrm{~mm}$, the ice initial melting times were $28 \mathrm{~s}, 30 \mathrm{~s}$ and $32 \mathrm{~s}$, respectively, and the corresponding final melting times were $44 \mathrm{~s}, 46 \mathrm{~s}$ and $48 \mathrm{~s}$, respectively.

Author Contributions: Conceptualization, W.J. and B.Z.; methodology, W.J.; software, W.J.; validation, B.Z., K.S. and W.J.; formal analysis, W.J.; investigation, W.J.; resources, W.J.; data curation, B.Z.; writing-original draft preparation, W.J.; writing-review and editing, B.Z., K.S. and W.J.; visualization, Y.X.; supervision, R.F.; project administration, R.F.; funding acquisition, Y.X. All authors have read and agreed to the published version of the manuscript.

Funding: This research was funded by [National key Research and development program] grant number [2018YFB0105501]. 
Conflicts of Interest: The authors declare no conflict of interest.

\section{Appendix A. Determination of the Heat Transfer Coefficient $\boldsymbol{h}_{\text {ext }}$}

The empirical formula proposed by QuanLi is given

$$
h_{c}=0.83 f\left(\frac{T_{s}-T_{\infty}}{P}\right)^{n}
$$

where $h_{c}$ is the surface convection heat transfer coefficient, $T_{s}$ is the surface temperature of the material, and $T_{\infty}$ is the external ambient temperature. In this paper, $T_{S}$ is set to $275 \mathrm{~K}$, which is the maximum PEMFC surface temperature. $T_{\infty}$ is set to $263 \mathrm{~K}$.

- When $f=1.22, n=0.35, h_{c}$ represents the vertical surface convection heat transfer coefficient, $P=H$;

- When $f=1.0, n=0.33, h_{c}$ represents the convection heat transfer coefficient of horizontal top surface, $P=\frac{W . L}{2(W+L)}$

- When $f=0.5, n=0.33, h_{c}$ represents the convection heat transfer coefficient of horizontal bottom surface;

- Where $L$ is the length of the horizontal plane, $W$ is the width of the horizontal plane, and $H$ is the vertical height.

The paper uses a 40-layer two-dimensional PEMFC stack with an overall size of $70 \mathrm{~mm} \times 132.8 \mathrm{~mm}$. The actual stack length and width are equal, that is, $W=L=70 \mathrm{~mm}$. It can be deduced that the top and bottom boundary convection heat transfer coefficients are $7.16 \mathrm{~W} / \mathrm{m}^{3} \cdot \mathrm{K}$ and $3.58 \mathrm{~W} / \mathrm{m}^{3} \cdot \mathrm{K}$, respectively, and vertical boundary convection heat transfer coefficient is $4.89 \mathrm{~W} / \mathrm{m}^{3} \cdot \mathrm{K}$.

\section{Appendix B. Determination of Thermal Conductivity and Volume Power Density of the ETF}

In this paper, the carbon nanotube film is used for the ETF. Young et al. [13] studied the electrothermal performance of the carbon nanotube film and calculated the convective heat transfer coefficient of the carbon nanotube film. The maximum value is $7.4 \mathrm{~W} / \mathrm{m}^{3}$. K. The ETF actual thickness is $0.1 \mathrm{~mm}$, and the thermal conductivity of the ETF can be calculated according to the following:

$$
k=h / l \text {, }
$$

where $k$ is the thermal conductivity, $h$ is the convective heat transfer coefficient of the carbon nanotube film, and $l$ is the thickness of the carbon nanotube film.

Young et al. concluded that the carbon nanotube film can be heated to $176{ }^{\circ} \mathrm{C}$ when the voltage is $10 \mathrm{~V}$. The paper uses ANSYS-ICEPAK software to establish the same structure as what studied by Young et al. The same voltage is applied at $10 \mathrm{~V}$ to reach $176{ }^{\circ} \mathrm{C}$. The thermal conductivity is the reversed calculation of $0.175 \mathrm{~W} / \mathrm{m} \cdot \mathrm{K}$, and the calculation result is shown in Figure A1.

In summary, due to the small difference in thermal conductivity between the two methods, the thermal conductivity of the electric heating film is $0.18 \mathrm{~W} / \mathrm{m} \cdot \mathrm{K}$.

Young et al.'s results also show that under the load of 1-2 W, the temperature can be increased to $176{ }^{\circ} \mathrm{C}$ The article also uses ANSYS-ICEPAK software, and applies a thermal conductivity of $0.18 \mathrm{~W} / \mathrm{m} \cdot \mathrm{K}$ to study the loaded power when the temperature rise reaches $176^{\circ} \mathrm{C}$. The calculational results are shown in Figure A2:

The calculation results show that the temperature can reach $176^{\circ} \mathrm{C}$ when the power is $1.2 \mathrm{~W}$, so the power of the electric heating film is $1.2 \mathrm{~W}$. According to the actual structure of the electric heating film, the power density is $1 \times 10^{7} \mathrm{~W} / \mathrm{m}^{3}$. 


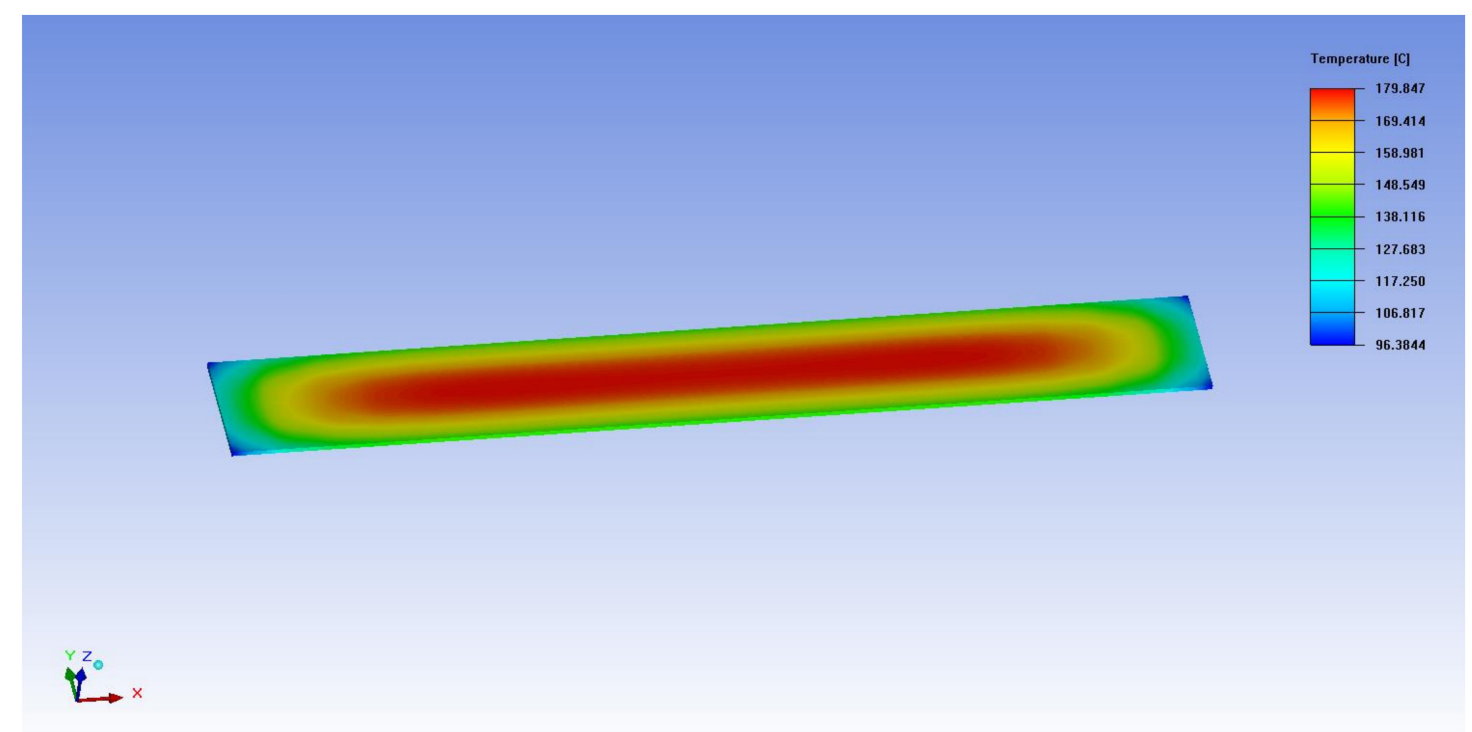

Figure A1. Calculation result of the thermal conductivity.

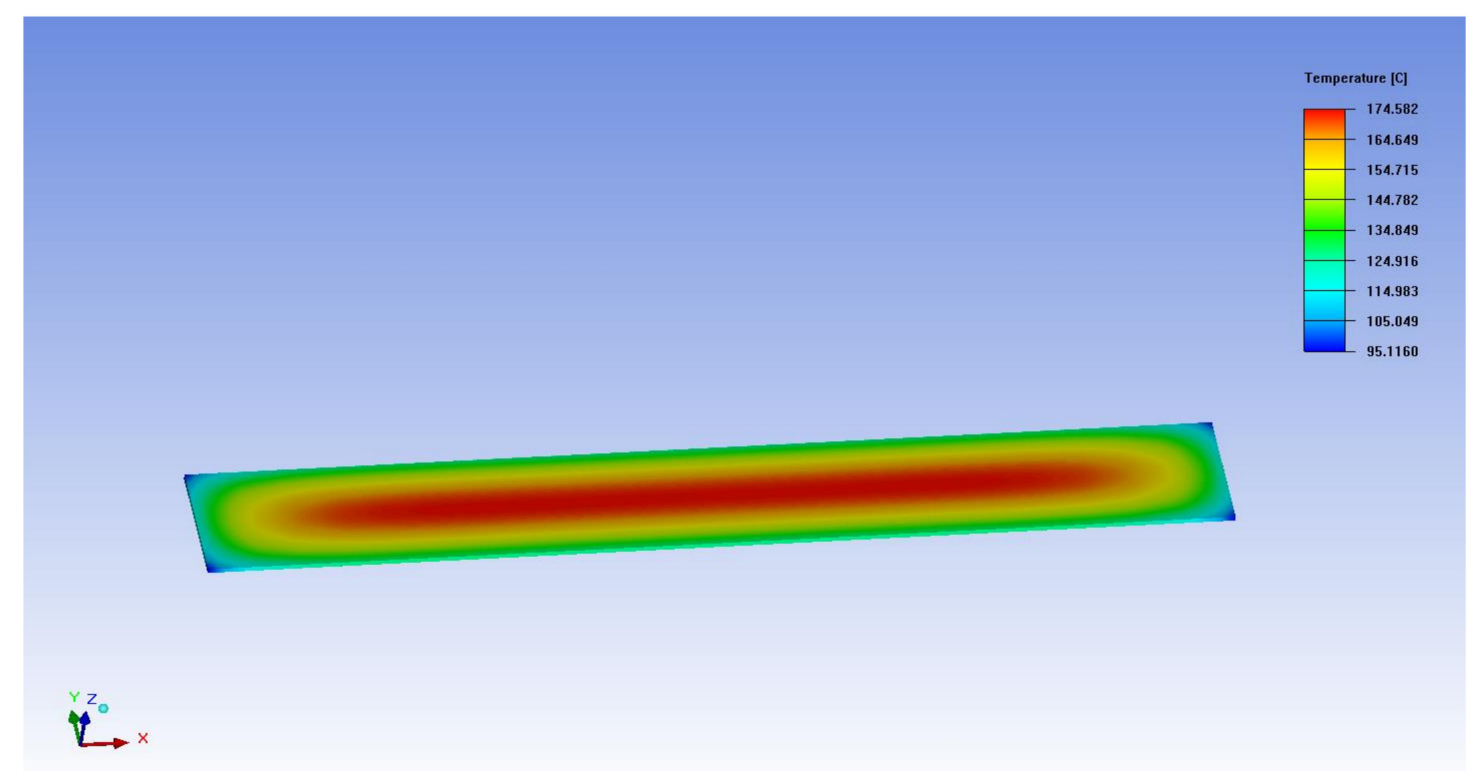

Figure A2. The calculation result of temperature. 


\section{Appendix C. The Units of Variables}

Table A1. The unit of variables

\begin{tabular}{|c|c|c|}
\hline Symbol & Variable & Units \\
\hline$\rho_{\mathrm{s}}$ & density of solid & \multirow{4}{*}{$\mathrm{kg} \mathrm{m}^{-3}$} \\
\hline$\rho_{q}$ & density of $q^{\text {th }}$ fluid & \\
\hline$\rho_{\mathrm{f}}$ & density of fulid & \\
\hline$p$ & density & \\
\hline$k_{\mathrm{s}}$ & thermal conductivity of the solid phase. & \multirow{3}{*}{$\mathrm{W} \mathrm{m}^{-1} \mathrm{~K}^{-1}$} \\
\hline$k_{\mathrm{f}}$ & thermal conductivity of the liquid phase & \\
\hline$k_{\text {eff }}$ & effective thermal conductivity of the medium & \\
\hline$\alpha_{q}$ & the $q^{\text {th }}$ fluid's volume fraction & \\
\hline$v$ & velocity of $q^{\text {th }}$ fluid & \multirow{2}{*}{$\mathrm{m} \cdot \mathrm{s}^{-1}$} \\
\hline $\overrightarrow{v_{q}}$ & velocity vector & \\
\hline$S_{a_{q}}$ & source term & \multirow{2}{*}{ W.m $\mathrm{m}^{-3}$} \\
\hline$S_{\mathrm{h}}$ & source term & \\
\hline$\dot{m}_{p q}$ & the mass transfer from phase $q$ to phase $p$ & \multirow{2}{*}{$\mathrm{kg}$} \\
\hline$\dot{m}_{q p}$ & the mass transfer from phase $p$ to phase $q$ & \\
\hline$h$ & enthalpy & \multirow{4}{*}{$\mathrm{kJ} / \mathrm{kg}$} \\
\hline$h_{\mathrm{q}}$ & enthalpy of $q^{\text {th }}$ fluid & \\
\hline$\Delta H$ & enthalpy variation & \\
\hline$h_{r e f}$ & reference enthalpy & \\
\hline$c_{p}$ & specific heat & $\mathrm{J} \cdot \mathrm{kg}^{-1} \cdot \mathrm{K}^{-1}$ \\
\hline$\beta$ & volume fraction of the liquid & \\
\hline$L$ & latent heat of liquid water & $\mathrm{J} . \mathrm{kg}^{-1}$ \\
\hline$T_{\mathrm{q}}$ & temperature of q-phase & \multirow{6}{*}{ K } \\
\hline$T_{\mathrm{fs}}$ & temperature of the porous medium region & \\
\hline$T_{w}$ & outer surface temperature of the material & \\
\hline$T_{\text {ext }}$ & external ambient temperature & \\
\hline$T_{\text {solidus }}$ & temperature of water starts to freeze & \\
\hline$T_{\text {liquidus }}$ & temperature of liquid begins to melt & \\
\hline$\gamma$ & porosity of the porous medium & \\
\hline$E_{\mathrm{q}}$ & energy of $q^{\text {th }}$ fluid & $\mathrm{J}$ \\
\hline$E_{\mathrm{f}}$ & total energy of the fluid & $\mathrm{J}$ \\
\hline$E_{\mathrm{s}}$ & total energy of the solid medium & $\mathrm{J}$ \\
\hline$h_{\text {ext }}$ & convective heat transfer coefficient & $\mathrm{W} /\left(\mathrm{m}^{2}{ }^{\circ} \mathrm{C}\right)$ \\
\hline
\end{tabular}

\section{References}

1. Cano, Z.P.; Banham, D.; Ye, S.; Hintennach, A.; Lu, J.; Fowler, M.; Chen, Z. Batteries and fuel cells for emerging electric vehicle markets. Nat. Energy 2018, 3, 279-289. [CrossRef]

2. Knorr, F.; Sanchez, D.G.; Schirmer, J.; Gazdzicki, P.; Friedrich, K.A. Methanol as antifreeze agent for cold start of automotive polymer electrolyte membrane fuel cells. Appl. Energy 2019, 238, 1-10. [CrossRef] 
3. Li, L.; Wang, S.; Yue, L.; Wang, G. Cold-start icing characteristics of proton-exchange membrane fuel cells. Int. J. Hydrogen Energy 2019, 44, 12033-12042. [CrossRef]

4. Hou, J.; Yu, H.; Zhang, S.; Sun, S.; Wang, H.; Yi, B.; Ming, P. Analysis of PEMFC freeze degradation at $-20^{\circ} \mathrm{C}$ after gas purging. J. Power Sources 2006, 162, 513-520. [CrossRef]

5. Huo, S.; Jiao, K.; Park, J.W. On the water transport behavior and phase transition mechanisms in cold start operation of PEM fuel cell. Appl. Energy 2019, 233-234, 776-788. [CrossRef]

6. Jiao, K.; Li, X. Three-dimensional multiphase modeling of cold start processes in polymer electrolyte membrane fuel cells. Electrochim. Acta 2009, 54, 6876-6891. [CrossRef]

7. Jean, B.S.; Marcelo, D.V. Global Change, Energy Issues and Regulation Policies; Integrated Science and Technology Program; Springer: Dordrecht, The Netherlands, 2013.

8. Jiao, K.; Alaefour, I.E.; Karimi, G.; Li, X. Simultaneous measurement of current and temperature distributions in a proton exchange membrane fuel cell during cold start processes. Electrochim. Acta 2011, 56, 2967-2982. [CrossRef]

9. Du, Q.; Jia, B.; Luo, Y.Q.; Chen, J.; Zhou, Y.; Jiao, K. Maximum power cold start mode of proton exchange membrane fuel cell. Int. J. Hydrogen Energy 2014, 39, 8390-8400. [CrossRef]

10. Kim, S.I.; Lee, N.W.; Kim, Y.S.; Kim, M.S. Effective purge method with addition of hydrogen on the cathode side for cold start in PEM fuel cell. Int. J. Hydrogen Energy 2013, 38, 11357-11369. [CrossRef]

11. Guo, Q.; Luo, Y.Q.; Jiao, K. Modeling of assisted cold start processes with anode catalytic hydrogen-oxygen reaction in proton exchange membrane fuel cell. Int. J. Hydrogen Energy 2013, 38, 1004-1015. [CrossRef]

12. Zhan, Z.; Yuan, C.; Hu, Z.; Wang, H.; Sui, P.C.; Djilali, N.; Pan, M. Experimental study on different preheating methods for the cold-start of PEMFC stacks. Energy 2018, 162, 1029-1040. [CrossRef]

13. Jeong, Y.G.; Jeon, G.W. Microstructure and performance of multiwalled carbon nanotube/m-aramid composite films as electric heating elements. ACS Appl. Mater. Interfaces 2013, 5, 6527-6534. [CrossRef] [PubMed]

14. Janas, D.; Koziol, K.K. Rapid electrothermal response of high-temperature carbon nanotube film heaters. Carbon 2013, 59, 457-463. [CrossRef]

15. Biercuk, M.J.; Llaguno, M.C.; Radosavljevic, M.; Hyun, J.K.; Johnson, A.T.; Fischer, J.E. Carbon nanotube composites for thermal management. Appl. Phys. Lett. 2002, 80, 2767-2769. [CrossRef]

16. Jang, H.-S.; Jeon, S.K.; Nahm, S.H. The manufacture of a transparent film heater by spinning multi-walled carbon nanotubes. Carbon 2011, 49, 111-116. [CrossRef]

17. Yan, J.; Jeong, Y.G. Multiwalled carbon nanotube/polydimethylsiloxane composite films as high performance flexible electric heating elements. Appl. Phys. Lett. 2014, 105, 051907. [CrossRef]

18. Xiao, Z.; Sheng, C.; Xia, Y.; Yu, X.; Liang, C.; Huang, H.; Gan, Y.; Zhang, J.; Zhang, W. Electrical heating behavior of flexible thermoplastic polyurethane/Super-P nanoparticle composite films for advanced wearable heaters. J. Ind. Eng. Chem. 2019, 71, 293-300. [CrossRef]

19. Bai, B.C.; Kang, S.C.; Im, J.S.; Lee, S.H.; Lee, Y.-S. Effect of oxyfluorinated multi-walled carbon nanotube additives on positive temperature coefficient/negative temperature coefficient behavior in high-density polyethylene polymeric switches. Mater. Res. Bull. 2011, 46, 1391-1397. [CrossRef]

20. Zhang, T.Y.; Zhao, H.M.; Wang, D.Y.; Wang, Q.; Pang, Y.; Deng, N.Q.; Cao, H.-W.; Yang, Y.; Ren, T.-L. A super flexible and custom-shaped graphene heater. Nanoscale 2017, 9, 14357-14363. [CrossRef]

21. Tan, L.; Zeng, M.; Wu, Q.; Chen, L.; Wang, J.; Zhang, T.; Eckert, J.; Rümmeli, M.H.; Fu, L. Direct growth of ultrafast transparent single-layer graphene defoggers. Small 2015, 11, 1840-1846. [CrossRef]

22. Sui, D.; Huang, Y.; Huang, L.; Liang, J.; Ma, Y.; Chen, Y. Flexible and transparent electrothermal film heaters based on graphene materials. Small 2011, 7, 3186-3192. [CrossRef] [PubMed]

23. Tian, J.; Yang, J.; Yang, C.; Hao, S. Compression and reduction of graphene oxide aerogels into flexible, porous and functional graphene films. J. Mater. Sci. 2019, 54, 13147-13156. [CrossRef]

24. An, J.-E.; Jeong, Y.G. Structure and electric heating performance of graphene/epoxy composite films. Eur. Polym. J. 2013, 49, 1322-1330. [CrossRef]

25. Bae, J.J.; Lim, S.C.; Han, G.H.; Jo, Y.W.; Doung, D.L.; Kim, E.S.; Chae, S.J.; Huy, T.Q.; Van Luan, N.; Lee, Y.H. Heat Dissipation of Transparent Graphene Defoggers. Adv. Funct. Mater. 2012, 22, 4819-4826. [CrossRef]

26. Shin, K.-Y.; Hong, J.-Y.; Lee, S.; Jang, J. High electrothermal performance of expanded graphite nanoplatelet-based patch heater. J. Mater. Chem. 2012, 22, 23404-23410. [CrossRef]

27. Dutil, Y.; Rousse, D.R.; Salah, N.B.; Lassue, S.; Zalewski, L. A review on phase-change materials: Mathematical modeling and simulations. Renew. Sustain. Energy Rev. 2011, 15, 112-130. [CrossRef] 
28. Kang, J.; Kim, H.; Kim, K.S.; Lee, S.K.; Bae, S.; Ahn, J.H.; Kim, Y.-J.; Choi, J.-B.; Hong, B.H. High-performance graphene-based transparent flexible heaters. Nano Lett. 2011, 11, 5154-5158. [CrossRef]

29. Li, C.; Xu, Y.-T.; Zhao, B.; Jiang, L.; Chen, S.-G.; Xu, J.-B.; Fu, X.-Z.; Sun, R.; Wong, C.-P. Flexible graphene electrothermal films made from electrochemically exfoliated graphite. J. Mater. Sci. 2015, 51, 1043-1051. [CrossRef]

30. Luo, J.; Lu, H.; Zhang, Q.; Yao, Y.; Chen, M.; Li, Q. Flexible carbon nanotube/polyurethane electrothermal films. Carbon 2016, 110, 343-349. [CrossRef]

31. Su, X.; Li, H.; Lai, X.; Yang, Z.; Chen, Z.; Wu, W.; Zeng, X. Vacuum-assisted layer-by-layer superhydrophobic carbon nanotube films with electrothermal and photothermal effects for deicing and controllable manipulation. J. Mater. Chem. A 2018, 6, 16910-16919. [CrossRef]

32. Sun, H.; Chen, D.; Ye, C.; Li, X.; Dai, D.; Yuan, Q.; Chee, K.W.A.; Zhao, P.; Jiang, N.; Lin, C.-T. Large-area self-assembled reduced graphene oxide/electrochemically exfoliated graphene hybrid films for transparent electrothermal heaters. Appl. Surf. Sci. 2018, 435, 809-814. [CrossRef]

33. Chorin, A.J. Numerical solution of navier-stokes equations. Math. Comput. 1968, 22, 745-762. [CrossRef]

34. Ko, J.; Kim, W.-G.; Lim, Y.-D.; Ju, H. Improving the cold-start capability of polymer electrolyte fuel cells (PEFCs) by using a dual-function micro-porous layer (MPL): Numerical simulations. Int. J. Hydrogen Energy 2013, 38, 652-659. [CrossRef]

(C) 2020 by the authors. Licensee MDPI, Basel, Switzerland. This article is an open access article distributed under the terms and conditions of the Creative Commons Attribution (CC BY) license (http://creativecommons.org/licenses/by/4.0/). 